\title{
Catalytic Hydropyrolysis of Biomass using Molybdenum Sulfide Based Catalyst. Effect of Promoters
}

Stummann, Magnus Zingler; Hansen, Asger Baltzer; Hansen, Lars Pilsgaard; Davidsen, Bente; Rasmussen, Søren Birk; Viwel, Peter; Gabrielsen, Jostein; Jensen, Peter Arendt; Jensen, Anker Degn; Høj, Martin

Published in:

Energy and Fuels

Link to article, DOI:

10.1021/acs.energyfuels.8b04191

Publication date:

2019

Document Version

Peer reviewed version

Link back to DTU Orbit

Citation (APA):

Stummann, M. Z., Hansen, A. B., Hansen, L. P., Davidsen, B., Rasmussen, S. B., Viwel, P., Gabrielsen, J., Jensen, P. A., Jensen, A. D., \& Høj, M. (2019). Catalytic Hydropyrolysis of Biomass using Molybdenum Sulfide Based Catalyst. Effect of Promoters. Energy and Fuels, 33(2), 1302-1313.

https://doi.org/10.1021/acs.energyfuels.8b04191

\section{General rights}

Copyright and moral rights for the publications made accessible in the public portal are retained by the authors and/or other copyright owners and it is a condition of accessing publications that users recognise and abide by the legal requirements associated with these rights.

- Users may download and print one copy of any publication from the public portal for the purpose of private study or research.

- You may not further distribute the material or use it for any profit-making activity or commercial gain

- You may freely distribute the URL identifying the publication in the public portal 


\section{energy fuels:}

\section{Biofuels and Biomass}

Subscriber access provided by DTU Library

\section{Catalytic Hydropyrolysis of Biomass using Molybdenum Sulfide Based Catalyst. Effect of Promoters}

Magnus Stummann, Asger B. Hansen, Lars Pilsgaard Hansen, Bente Davidsen, Søren B. Rasmussen,

Peter Viwel, Jostein Gabrielsen, Peter Arendt Jensen, Anker Degn Jensen, and Martin Høj

Energy Fuels, Just Accepted Manuscript • DOI: 10.1021/acs.energyfuels.8b04191 • Publication Date (Web): 29 Jan 2019

Downloaded from http://pubs.acs.org on February 8, 2019

\section{Just Accepted}

"Just Accepted" manuscripts have been peer-reviewed and accepted for publication. They are posted online prior to technical editing, formatting for publication and author proofing. The American Chemical Society provides "Just Accepted" as a service to the research community to expedite the dissemination of scientific material as soon as possible after acceptance. "Just Accepted" manuscripts appear in full in PDF format accompanied by an HTML abstract. "Just Accepted" manuscripts have been fully peer reviewed, but should not be considered the official version of record. They are citable by the Digital Object Identifier (DOI®). "Just Accepted" is an optional service offered to authors. Therefore, the "Just Accepted" Web site may not include all articles that will be published in the journal. After a manuscript is technically edited and formatted, it will be removed from the "Just Accepted" Web site and published as an ASAP article. Note that technical editing may introduce minor changes to the manuscript text and/or graphics which could affect content, and all legal disclaimers and ethical guidelines that apply to the journal pertain. ACS cannot be held responsible for errors or consequences arising from the use of information contained in these "Just Accepted" manuscripts. 


\section{Catalytic Hydropyrolysis of Biomass using} Molybdenum Sulfide Based Catalyst. Effect of Promoters

\section{Abstract}

Catalytic hydropyrolysis of beech wood was conducted in a fluid bed reactor at $450^{\circ} \mathrm{C}$ and a total pressure of 26 bar. The differences in hydrodeoxygenation activity, selectivity and the resulting product composition between sulfided $\mathrm{Mo} / \mathrm{MgAl}_{2} \mathrm{O}_{4}, \mathrm{CoMo} / \mathrm{MgAl}_{2} \mathrm{O}_{4}$ or $\mathrm{NiMo} / \mathrm{MgAl}_{2} \mathrm{O}_{4}$ catalysts have been investigated. The acidity and molybdate species in the oxide catalyst precursors were characterized with ammonia temperature programmed desorption ( $\left.\mathrm{NH}_{3}-\mathrm{TPD}\right)$ and Raman spectroscopy. The spent sulfided catalysts were also extensively characterized by scanning electron microscopy (SEM) and by scanning transmission electron microscopy (STEM) coupled with energy dispersive X-ray spectroscopy (EDS). The catalytic hydropyrolysis of beech wood produced four kinds of products: Liquid organic and aqueous phases, solid char and gases. The solid char and aqueous phase yields were not affected by the type of catalyst. The sum of condensed organics and $\mathrm{C}_{4+}$ gas yield varied between 24.3 and 26.4 wt.\% on dry, ash free basis (daf) and was highest for the Mo catalyst and lowest for the NiMo catalyst. The NiMo catalyst had the highest hydrogenation, cracking, and de-carbonylation activity. The oxygen content in the condensed organic phase was between 9.0 and 12 wt.\% on dry basis $(\mathrm{db})$ and was lowest for the CoMo catalyst and highest for the 
24 Mo catalyst. The carbon recovery in the condensable organics was $39 \%$ for both the CoMo and the Mo, 25 and $37 \%$ for the NiMo catalyst. These results indicate that the CoMo, due to its high deoxygenation activity 26 and high carbon recovery, is the most suitable catalyst for catalytic hydropyrolysis. The carbon content on 27 the spent CoMo was between 1.5 and 3.3 wt.\% and between 0.9 and 3.1 on the spent NiMo catalyst, but 28 between 5.0 and 5.5 wt.\% on the spent Mo catalyst. The higher carbon content on the spent Mo catalyst 29 was probably due to its lower deoxygenation and hydrogenation activity. Calcium particles and small 30 amounts of potassium ( $\leq 1.5 \mathrm{wt} . \%)$ were detected on all spent catalysts using STEM-EDS, showing that alkali 31 metals are transferred from the biomass to the catalyst, which potentially could lead to catalyst 32 deactivation. 


\section{Abbreviations}

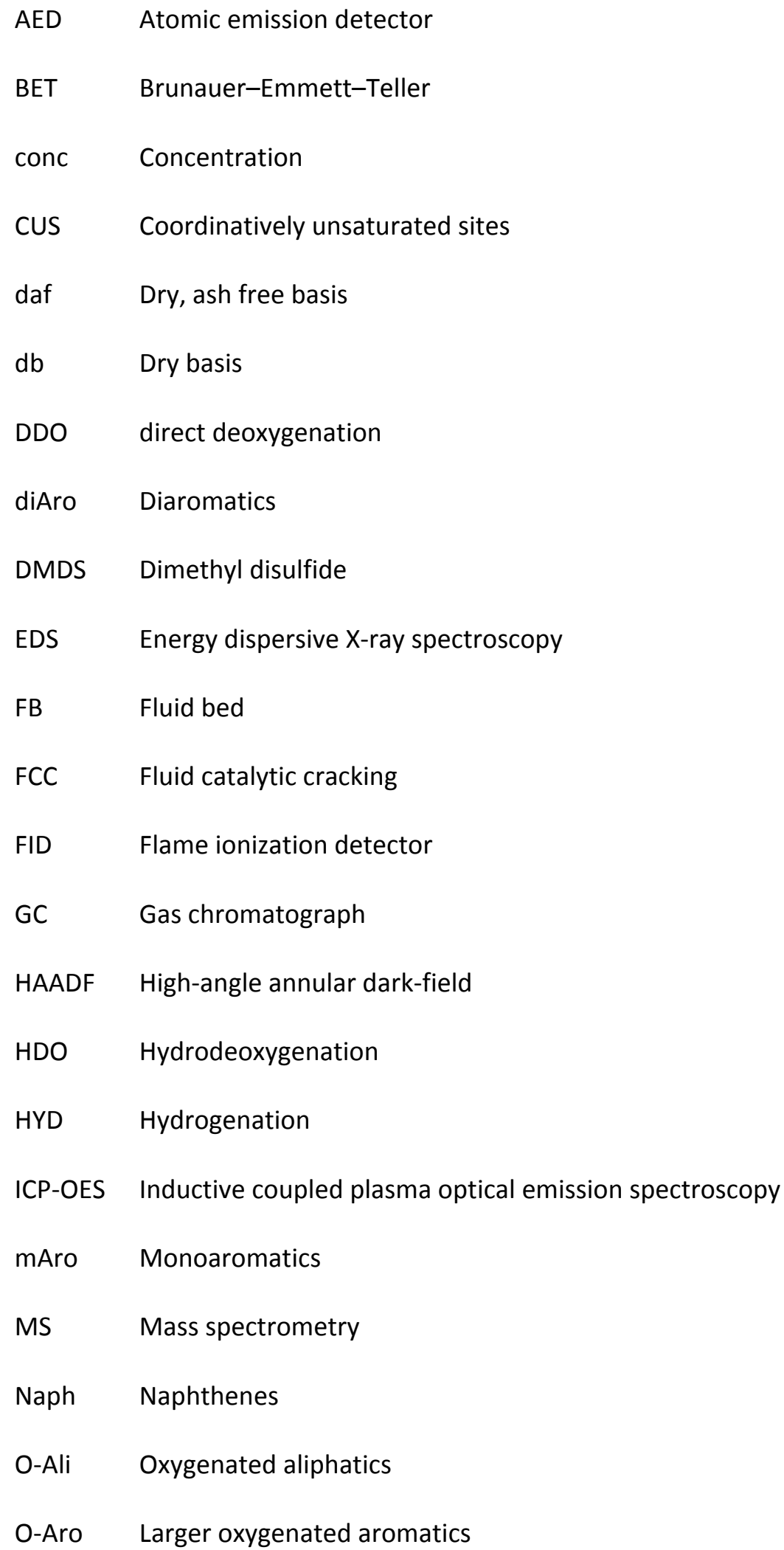


Par Paraffins

PhOH Phenolics

$\mathrm{Ph}(\mathrm{OH}) 2$ Dihydroxybenzene

SSA Specific surface area

SEM Scanning electron microscopy

STEM Scanning transmission electron microscopy

Temp. Temperature

TPD Temperature programmed desorption

tetAro+ Tetra- and higher aromatics

triAro Triaromatics

35

36

31

32 


\section{Introduction}

38

39

Catalytic hydropyrolysis, the concerted combination of fast pyrolysis and catalytic hydrodeoxygenation (HDO), has been shown to be an efficient method for production of renewable diesel and gasoline range hydrocarbons from biomass ${ }^{1,2}$. In this process the reactive oxygenates formed during pyrolysis, which otherwise may undergo polymerization reactions ${ }^{3}$, are immediately hydrogenated producing a stable product with a significantly lower oxygen content than conventional fast pyrolysis oil. Marker et al. ${ }^{1,2}$ were able to produce an oxygen free oil with a condensed organic and $C_{4+}$ gas yield of 21 to $46 \mathrm{wt} . \%$ dry ash free (daf) basis by conducting catalytic hydropyrolysis of different types of biomass (the high yield of 46 wt.\% daf was obtained with microalgae) in a fluid bed reactor followed by deep HDO in a fixed bed reactor, in a process called $\mathrm{IH}^{2 \circledast}$. Furthermore, life cycle assessments of the $\mathrm{IH}^{2 \circledast}$ process have shown that its fuel products have $30-96 \%$ lower greenhouse gas emissions compared to fossil fuels, mainly depending on the biomass feedstock where bagasse shows the highest reduction ${ }^{4,5}$.

Using a fluid bed reactor, Dayton et al. ${ }^{6-8}$ have tested several pre-reduced catalysts, including a commercial NiMo hydrotreating catalyst and a Mo based catalyst, for catalytic hydropyrolysis of woody biomass at temperatures between 375 and $500{ }^{\circ} \mathrm{C}$ and pressures of hydrogen between 1 and 31 bar. They were able to obtain a condensed organic and $\mathrm{C}_{4+}$ carbon yield of $43 \%$, with an oxygen content in the condensed liquid of 6.2 wt. $\%^{8}$. However, the composition of the catalysts was not reported and the spent catalysts were not characterized. Gamliel et al. ${ }^{9-11}$ also studied the effect of reduced metal catalysts in catalytic hydropyrolysis using a Pyroprobe analyzer focusing mainly on Ni metal on a zeolite (ZSM-5) support. The fresh catalysts were characterized, but the spent catalysts were not studied. Therefore, despite that catalytic hydropyrolysis is a promising technology, there is very little information available about the composition of catalysts and to what degree the catalysts may be deactivated e.g. by carbon deposition or transfer of alkali metals, inherently present in biomass. 
60 Sulfided CoMo, NiMo, and Mo, which are widely used as hydrotreating catalysts in oil refineries, are also 61 known to be active and stable in hydrodeoxygenation reactions of bio-oil and model components ${ }^{12-20}$. Since 62 most biomass sources contain sulfur ${ }^{21}$, a major advantage of the sulfided catalysts is that they are sulfur 63 tolerant, as opposed to many reduced metal catalysts. It is well-known that the addition of a promoter (Co or $\mathrm{Ni}$ ) to $\mathrm{MoS}_{2}$ increases the formation of the coordinated unsaturated sites (CUS) ${ }^{22-24}$, thus enhancing the catalytic activity ${ }^{17,25}$. One of the differences between $\mathrm{Co}$ and $\mathrm{Ni}$ as promoter is that Co promotes the direct deoxygenation (DDO) pathway, while Ni promotes the hydrogenation (HYD) pathway, where aromatic rings are saturated prior to deoxygenation ${ }^{18,25-28}$.

In our previous work we conducted catalytic hydropyrolysis of beech wood in a fluid bed reactor with a commercial, sulfided CoMo/MgAl $\mathrm{O}_{4}$ catalyst (supplied by Haldor Topsøe $A / S$ ), followed by a fixed bed reactor with a commercial, sulfided $\mathrm{NiMo} / \mathrm{Al}_{2} \mathrm{O}_{3}$ hydrotreating catalyst ${ }^{29}$. The effect of temperature and pressure in the fluid bed hydropyrolysis reactor was evaluated. An essentially oxygen free organic phase (oxygen<0.01 wt.\%) was obtained with a yield between 17 and $22 \mathrm{wt} . \%$ daf, corresponding to an energy recovery between 40 and $53 \%^{29}$. The concentration of aromatics could be controlled between 42 and $75 \%$ by varying the operating conditions ${ }^{29}$. Furthermore we previously studied the differences between sulfided Mo, CoMo, and NiMo, catalysts supported on $\mathrm{MgAl}_{2} \mathrm{O}_{4}$ in the hydrodeoxygenation of ethylene glycol in a fixed bed reactor ${ }^{17}$, and found that the Mo catalyst had the lowest conversion and the lowest stability, but the highest selectivity to $C_{2}$ and $C_{3}$ hydrocarbons and $C-C$ coupling products, rather than $C_{1}$ cracking products. This indicates that it could be an advantage to use a catalyst with a moderate activity in catalytic hydropyrolysis. 
obtain specific information about the surface molybdate species and acid properties. The spent catalysts were investigated with electron microscopy (SEM and STEM) coupled with energy dispersive X-ray

\section{$93 \quad 2$ Experimental}

\section{$94 \quad 2.1 \quad$ Biomass feedstock} the ash composition, can be found elsewhere ${ }^{29}$.

\subsection{Catalyst preparation}

The CoMo, NiMo, and Mo catalysts were prepared by sequential incipient wetness impregnation of the $\mathrm{MgAl}_{2} \mathrm{O}_{4}$ spinel support, which was supplied by Haldor Topsøe A/S. The support was crushed to a particle size of $180-355 \mu \mathrm{m}$, to ensure a good fluidization of the fluid bed. Prior to impregnation, the support was 
106 calcined at $995^{\circ} \mathrm{C}$ for 10 hours. The calcined support had a pore volume of $0.58-0.62 \mathrm{~g}$ water $/ \mathrm{g}$ and $110 \%$ of 107 this volume was used for the impregnation. The specific surface area (SSA) was between $54-58 \mathrm{~m}^{2} / \mathrm{g}$.

The support was impregnated with an aqueous solution of $\left(\mathrm{NH}_{4}\right)_{6} \mathrm{Mo}_{7} \mathrm{O}_{24} \cdot 4 \mathrm{H}_{2} \mathrm{O}$ (Fluka $\left.\geq 99.0 \%\right)$, then aged with stirring for approximately 3 hours and dried over night at approximately $110^{\circ} \mathrm{C}$ in air. For the promoted catalysts, a second impregnation with $\mathrm{Co}\left(\mathrm{NO}_{3}\right)_{2} \cdot 6 \mathrm{H}_{2} \mathrm{O}$ (Fluka $\geq 98 \%$ ) or $\mathrm{Ni}\left(\mathrm{NO}_{3}\right)_{2} \cdot 6 \mathrm{H}_{2} \mathrm{O}(\mathrm{Sigma}$ Aldrich $\geq 97 \%$ ) was conducted with ageing for approximately 3 hours followed by drying over night at approximately $110^{\circ} \mathrm{C}$ in air. The calcination was conducted under a flow of technical air by heating to $500^{\circ} \mathrm{C}$ with a ramp of $5^{\circ} \mathrm{C} / \mathrm{min}$ and holding for 3 hours. After calcination the catalyst was sieved to $180-355 \mu \mathrm{m}$ again in order to remove any dust or agglomerates formed during the preparation. The composition of the catalysts is shown in Table 1. A Mo loading between 3.5 and 3.7 atoms $/ \mathrm{nm}^{2}$ was obtained. Mo loadings

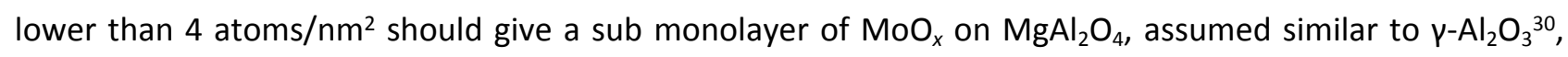
which should lead to a high dispersion of small $\mathrm{MoS}_{2}$ particles (when sulfided) with a moderate activity, hence minimizing the formation of the very active type II sites ${ }^{31}$. The (Co/Ni) to Mo atomic ratio was aimed at 0.3 , because this should ensure that the less active $\mathrm{Co}_{9} \mathrm{~S}_{8}$ phase is not formed ${ }^{32}$. The acidity of the as calcined catalysts in the oxide form was measured using $\mathrm{NH}_{3}$ adsorption and subsequent TPD. No significant difference in the acidity of the three catalysts was observed (see supporting information Figure S.1 and Table S.1), indicating that the main difference between these catalysts are the promoter.

The catalysts were sulfided in-situ in the catalytic hydropyrolysis setup at 26 bar, $350^{\circ} \mathrm{C}$ with $1.8 \mathrm{~mol} \% \mathrm{H}_{2} \mathrm{~S}$, $11 \mathrm{~mol} \% \mathrm{~N}_{2}$ in $87 \mathrm{~mol} \% \mathrm{H}_{2}$ by feeding $2 \% \mathrm{H}_{2} \mathrm{~S}$ in $\mathrm{H}_{2}$ (flow: $4 \mathrm{NL} / \mathrm{min}$ ) and $\mathrm{N}_{2}$ (flow: $0.5 \mathrm{NL} / \mathrm{min}$ ). The temperature ramp was $10{ }^{\circ} \mathrm{C} / \mathrm{min}$ and the holding time was 2 hours. After the sulfidation, the test conditions shown in Table 2 were established. 
Table 1 Composition of the fresh catalysts

\begin{tabular}{lcccccc}
\hline Catalyst & $\begin{array}{c}\mathrm{Mo} \\
{[w \mathrm{wt} \%]}\end{array}$ & $\begin{array}{c}\mathrm{Ni} \\
{[\mathrm{wt} . \%]}\end{array}$ & $\begin{array}{c}\mathrm{Co} \\
{[\mathrm{wt.} \%]}\end{array}$ & $\begin{array}{c}\text { (Co/Ni)/Mo } \\
{[\mathrm{molar}]}\end{array}$ & $\begin{array}{c}\text { Mo load } \\
\text { Atoms } / \mathrm{nm}^{2}\end{array}$ & $\begin{array}{c}\mathrm{BET} \text { SSA } \\
\mathrm{m}^{2} / \mathrm{g}\end{array}$ \\
\hline CoMo & 3.41 & - & 0.637 & 0.30 & 3.6 & 60 \\
NiMo & 3.27 & 0.585 & - & 0.29 & 3.5 & 58 \\
Mo & 3.50 & - & - & - & 3.7 & 60 \\
\hline
\end{tabular}

\section{9}

14

15130 16

17

\subsection{Experimental setup}

The catalytic hydropyrolysis experiments were conducted in a bench scale setup shown schematically in Figure 1 and described in detail elsewhere ${ }^{29}$. In brief, the setup consisted of a feeding system, which included a gas mixing system and a screw feeder for biomass feeding, a fluid bed hydropyrolysis reactor, a filter for char removal and a three stage condensation system $\left(20^{\circ} \mathrm{C}, 2^{\circ} \mathrm{C}\right.$, and $\left.-40^{\circ} \mathrm{C}\right)$. The uncondensed gases were sent to a flare. A small fraction of the gas was set to an online gas GC, which measured the gas composition $\left(\mathrm{H}_{2}, \mathrm{~N}_{2}, \mathrm{H}_{2} \mathrm{~S}, \mathrm{CO}, \mathrm{CO}_{2}, \mathrm{C}_{1}\right.$ to $\mathrm{C}_{5}$ and $\mathrm{C}_{6+}$ hydrocarbons) every $10 \mathrm{~min}$. The piping between the fluid bed, filter and condensation section was heated to $350^{\circ} \mathrm{C}$ in order to avoid condensation. During the experiments $52 \mathrm{NL} / \mathrm{min}$ hydrogen passed through a sinter plate in the bottom of the fluid bed reactor and $30 \mathrm{NL} / \mathrm{min}$ hydrogen and $5 \mathrm{NL} / \mathrm{min}$ nitrogen passed through the biomass feeding tube, thus ensuring a rapid transfer of the biomass from the screw feeder to fluid bed reactor. The fluid bed temperature was approximately $450^{\circ} \mathrm{C}$, the biomass feeding rate was between 271 and $275 \mathrm{~g} / \mathrm{h}$, the total pressure was 26 bar, and the experimental time was $3.5 \mathrm{~h}$. The condensed liquid was collected after the experiment had ended.

The total mass of the condensed liquid was determined by weighing and the organic phase and the aqueous phase were separated with a separation funnel. The mass of the aqueous phase was measured and the mass of the organic phase was determined by subtracting the mass of the aqueous phase from the total mass of condensed liquid. The $\mathrm{H}_{2} \mathrm{~S}$ dissolved in the liquid phases was for safety reasons removed by bubbling with $\mathrm{N}_{2}$ until hydrogen sulfide test strips (Sigma Aldrich) showed no sign of $\mathrm{H}_{2} \mathrm{~S}$. This lead to a mass loss between 0 and $4.8 \mathrm{wt} . \%$ for the organic phase and between 1.0 and $1.5 \mathrm{wt} . \%$ of the aqueous 
phase. The mass loss in the organic phase was mainly due to vaporization of light hydrocarbons while the 150 mass loss in the aqueous phase was mainly due to vaporization of water.

After each experiment the catalyst and the remaining char was removed from the fluid bed, and replaced with the fresh catalyst for the subsequent experiment. The sum of char (un-vaporized biomass residue) and

coke (carbon on the catalysts) yield was calculated by subtracting the mass of loaded catalyst from the total mass of solids collected from the filter and fluid bed.

Regarding the experimental uncertainty, a previously reported repeated experiment ${ }^{33}$ has shown that the largest uncertainty is the aqueous phase yield, where the difference between two experiments was 1.2 wt. $\%$ daf. The difference in the $\mathrm{C}_{1}-\mathrm{C}_{3}$ yield was $<0.1$ wt. $\%$ daf, $\mathrm{CO}$ and $\mathrm{CO}_{2}$ yield was 0.4 wt. $\%$ daf, char and coke yield was $0.1 \mathrm{wt.} \%$ daf, and condensed organics and $\mathrm{C}_{4+}$ in the gas yield was 0.1 wt. $\%$ daf. It is therefore assumed that the experimental error is less than $0.5 \mathrm{wt} . \%$ daf for the char and coke yield, 0.2 wt.\% daf for the $\mathrm{C}_{1}-\mathrm{C}_{3}$ yield, $0.5 \mathrm{wt}$ \% daf for the total $\mathrm{CO}$ and $\mathrm{CO}_{2}$ yield, $1.5 \mathrm{wt} \%$ for the aqueous phase yield, and less than $0.5 \mathrm{wt} . \%$ daf for the condensed organics and $\mathrm{C}_{4_{+}}$in the gas yield. 


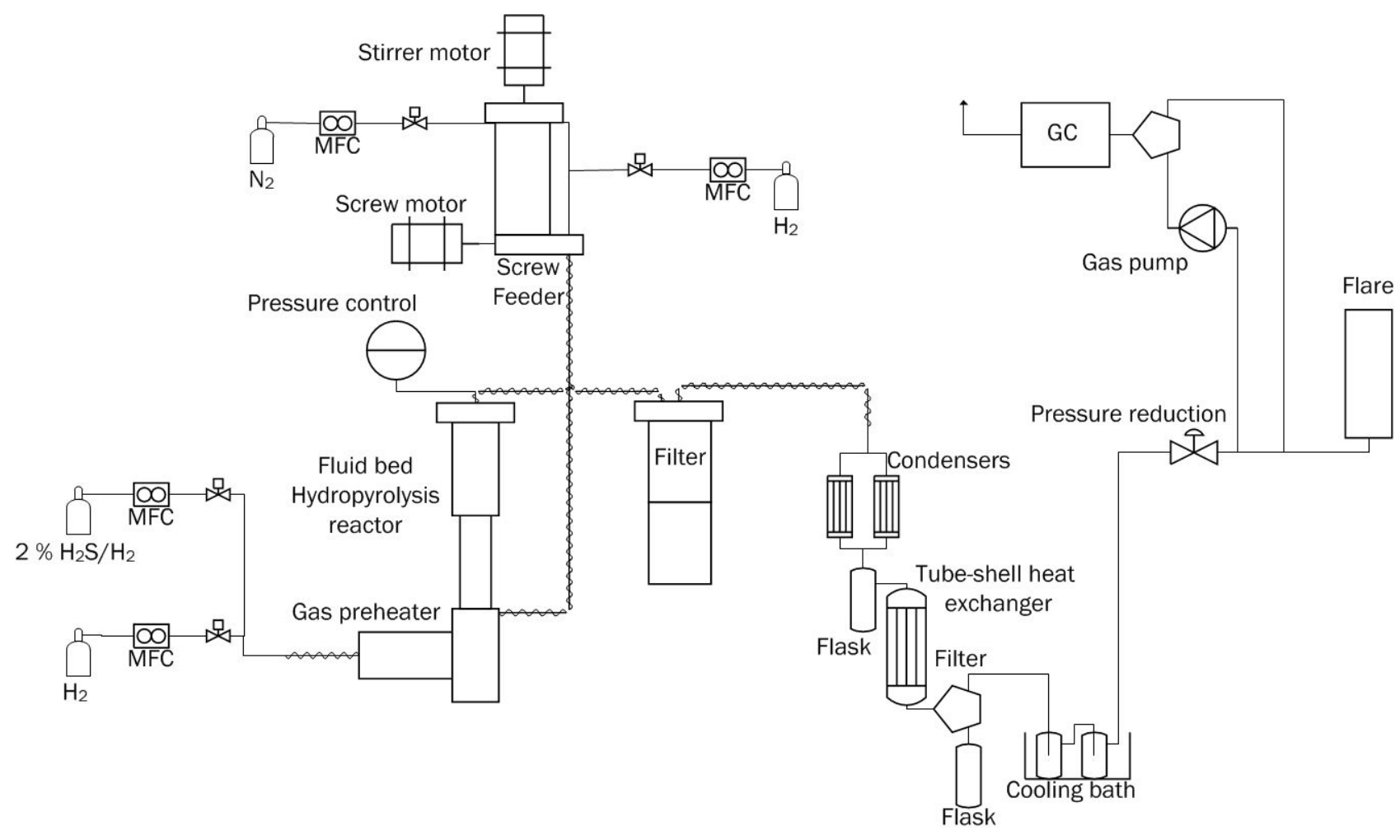

Figure 1. Simplified piping and instrumentation diagram of the catalytic hydropyrolysis setup

\subsection{Analysis methods}

\subsubsection{Organic phase}

Several methods were used to analyze the condensed organic phase and a more detailed description can be found elsewhere ${ }^{29}$. The hydrogen content was measured with the ASTM method D7171. The sulfur content was measured according to ASTM D4294. The density at $40{ }^{\circ} \mathrm{C}$ was measured with ASTM method D 4052 and the water content was measured with Karl Fisher titration. 
175 into seven groups: paraffins, naphthenes, mono-, di- and tri- and higher aromatics, oxygenated aliphatics, 176 phenolics, dihydroxybenzenes, larger oxygenated aromatics, and sterols. The relative uncertainty for this 177 analysis is estimated to be below $5 \%$.

Selective analysis of sulfur containing compounds was conducted using a GC with an atomic emission detector (AED) ${ }^{29}$.

\subsubsection{Aqueous phase}

The carbon content in the aqueous phase samples was determined with GC-AED using an Agilent 7890A GC coupled to a JAS 2370 AED in carbon selective mode. The carbon emission line at $193 \mathrm{~nm}$ was used in combination with a helium makeup gas flow of $80 \mathrm{ml} / \mathrm{min}$. The cavity temperature was $320^{\circ} \mathrm{C}$ and the transfer line temperature was $380^{\circ} \mathrm{C}$. The GC column was a Phenomenex ZB-5 Inferno $(30 \mathrm{~m} \mathrm{X} 0.25 \mathrm{~mm} \mathrm{X}$ $0.25 \mu \mathrm{m})$ in connection with a JAS PTV inlet in split mode $(1: 100)$ held at $325^{\circ} \mathrm{C}$ and $0.5 \mu \mathrm{l}$ injection. The oven was held at $40^{\circ} \mathrm{C}$ for $1 \mathrm{~min}$ and then ramped to $380^{\circ} \mathrm{C} @ 10^{\circ} \mathrm{C} / \mathrm{min}$. The quantification was done by external standards using benzyl alcohol dissolved in water. Calibration concentrations ranged from $10 \mathrm{ppm}$ to $1100 \mathrm{ppm}$ carbon. No identification of individual compounds was done and the total detected carbon was taken as a figure of the total carbon content in the aqueous sample. No sample pretreatment was done prior to analysis.

The aqueous phase was also analyzed on a Shimadzu GC-MS/FID as previously described ${ }^{29}$. Based on the GC-FID/MS analysis the components were classified into 8 groups: unidentified, ethers, ketones, alcohols, sugars, phenols, acids and furans. The relative amount (FID area-\%) of each component class was estimated as the sum of all the detected peaks in that class divided by the total peak area.

\subsubsection{Catalyst characterization}

The composition ( $\mathrm{Co}, \mathrm{Ni}, \mathrm{Mo}$ ) of the fresh catalysts was determined with inductive coupled plasma optical emission spectroscopy (ICP-OES) and the surface area was measured with $\mathrm{N}_{2}$-physisorption (BET). Temperature programmed ammonia desorption $\left(\mathrm{NH}_{3}-\mathrm{TPD}\right)$ of the fresh catalysts were conducted on a 
Mettler Toledo TGA/DSC 1. A complete blank measurement was first conducted with an empty crucible.

200 The sample was subjected to the same procedure, which was heating at $20^{\circ} \mathrm{C} / \mathrm{min}$ to $500{ }^{\circ} \mathrm{C}$, where the sample was held for $60 \mathrm{~min}$ in $75 \mathrm{ml} / \mathrm{min} 31 \% \mathrm{He}$ and $69 \%$ Ar. Thereafter the sample was cooled to $150^{\circ} \mathrm{C}$ $\left(-20^{\circ} \mathrm{C} / \mathrm{min}\right)$, and left to settle at $150^{\circ} \mathrm{C}$ for 20 minutes. The gas was then changed to $75 \mathrm{ml} / \mathrm{min} 2 \% \mathrm{NH}_{3}$ in $29 \% \mathrm{He}$ and $69 \% \mathrm{Ar}$ for $30 \mathrm{~min}$ and the sample was flushed in the Ar/He mixture for $233 \mathrm{~min}$. Afterwards the sample was cooled to $140^{\circ} \mathrm{C}$ and the $\mathrm{NH}_{3}$ desorption ramp $\left(10 \mathrm{C}^{\circ} / \mathrm{min}\right)$ up to $600^{\circ} \mathrm{C}$ was initiated. To assess the desorbed $\mathrm{NH}_{3}$ the weight loss in the temperature interval $150-500^{\circ} \mathrm{C}$ was used.

Raman spectroscopy on the calcined oxide catalyst precursors was performed at ambient conditions with a Labram 800 HR from Jobin Yvon using a Koheras solid state 488 nm laser.

The scanning electron microscopy (SEM) was performed on a FEI QUANTA600 scanning electron microscope with tungsten filament and equipped with a liquid nitrogen cooled EDAX ultra-thin window (UTW) EDS detector. All samples were sprinkled on carbon tabs on Al-stubs and conducted without any coating to prevent charging in the sample chamber.

EDS element quantifications were acquired on $0.11 \mathrm{~mm} \times 0.11 \mathrm{~mm}$ areas on the surface of the catalyst grains at acceleration voltages of $3 \mathrm{kV}, 5 \mathrm{kV}, 10 \mathrm{kV}$ and $15 \mathrm{kV}$ to probe different interaction volumes between the incident electron beam and the sample. The composition of the sample was determined in EDAX software (version 5.2.42) using a normalized, standardless, ZAF-corrected and SEC-factor corrected quantification of the acquired EDS-spectra. The maximum penetration depth of the incident electron beam in $\mathrm{MgAl}_{2} \mathrm{O}_{4}$ was estimated with the CASINO Monte Carlo Software v.3.3.04 (see Table S.2, Figures S.2 and Figure S.3) to be approximately $0.170 \mu \mathrm{m}$ for $3 \mathrm{kV}$ and $1.60 \mu \mathrm{m}$ for $15 \mathrm{kV}$, and serves as a rough indication of the maximum depth from where the detected X-rays may have been generated. The standard deviation for the carbon measurement was $1.5 \mathrm{wt} . \%$ at $3 \mathrm{kV}, 0.8 \mathrm{wt} . \%$ at $5 \mathrm{kV}, 1.0 \mathrm{wt} . \%$ at $10 \mathrm{kV}$ and $1.5 \mathrm{wt} . \%$ at 15 $\mathrm{kV}$, and the standard deviation for the potassium measurements was $0.6 \mathrm{wt} . \%$ at $5 \mathrm{kV}, 0.3 \mathrm{wt} . \%$ at $10 \mathrm{kV}$, and $0.2 \mathrm{wt} . \%$ at $15 \mathrm{kV}$. 
223 The transmission electron microscopy was performed on a FEl Talos ${ }^{\mathrm{TM}}$ F200X transmission electron 224 microscope equipped with high-brightness field emission gun (X-FEG) and Super-X G2 EDS detector. The 225 catalyst powders were crushed in a mortar and dispersed dry on a CU TEM grid covered by a continuous 10

carbon film (SPI Supplies). Images and elemental EDS maps were acquired in scanning transmission mode (STEM) with a camera length of $125 \mathrm{~cm}$. Elemental EDS maps of 512 pixels $\times 512$ pixels $(2.1 \mu \mathrm{m} \times 2.1 \mu \mathrm{m})$ were acquired for 22 min in Brüker software (Esprit 1.9) using a probe current of $0.7 \mathrm{nA}$. It is noted that the EDS sulfur $\mathrm{K}$-line $\left(\mathrm{S}-\mathrm{K}_{\alpha} 2.309 \mathrm{keV}\right)$ may overlap with the molybdenum L-line (Mo- $\mathrm{L}_{\alpha} 2.292 \mathrm{keV}$ ) as the separation in energy is less than the EDS resolution of about $0.13 \mathrm{keV}$ (full-width-half-maximum of $\mathrm{Mn}-\mathrm{K}_{\alpha}$ peak). Therefore, the elemental maps were processed in Esprit by a Bremsstrahlung background subtraction and series deconvolution of the EDS pixel spectra (using a 4x-binning) to display the net counts of Mo-K $\mathrm{K}_{\alpha}(17.480 \mathrm{keV}), \mathrm{S}-\mathrm{K}_{\alpha}(2.309 \mathrm{keV}), \mathrm{Co}^{-K_{\alpha}}(6.931 \mathrm{keV}), \mathrm{Ni}-\mathrm{K}_{\alpha}(7.480 \mathrm{keV}), \mathrm{K}-\mathrm{K}_{\alpha}(3.314 \mathrm{keV})$, and Ca-K $\mathrm{K}_{\alpha}$ (3.692 keV) respectively. The EDS analyses were complimented by high-resolution STEM imaging (probe size about $0.16 \mathrm{~nm}$ ) using the high-angle annular dark field detector (HAADF). For particle size measurements, HAADF-STEM images of 1024 pixels x 1024 pixels were recorded with a pixel size of 0.061 $\mathrm{nm}$ thus enabling the lattice spacing of $2 \mathrm{H}_{-}-\mathrm{MoS}_{2}(001)$ of $0.615 \mathrm{~nm}$ to be resolved. The sizes of the identified particles were measured manually from the images using ImageJ software.

\section{Results and Discussion}

The reaction conditions, mass balance and properties of the condensed liquid phases are shown in Table 2 .

The mass balance for the experiments closed between 96.7 and 99.1 wt.\% daf. A more detailed gas composition is shown in supporting information Table S.3.

Table 2 Summary of reaction conditions and mass balance for catalytic hydropyrolysis of beech wood in fluid bed reactor with sulfided CoMo, NiMo and Mo as catalysts. (Catalyst used: $\mathbf{5 0 . 0}$ g catalyst, feed time: 3.5 hours, Pressure 26 bar, $\mathrm{H}_{2}$ flow: 82 $\mathrm{NL} / \mathrm{min}, \mathrm{N}_{2}$ flow: $5 \mathrm{NL} / \mathrm{min}$, and $\mathrm{H}_{2} \mathrm{~S}$ conc: $460 \mathrm{ppm}$ )

\begin{tabular}{lccc}
\hline Test: & CoMo & NiMo & Mo \\
\hline Test conditions & & & \\
Hydropyrolysis Temp. $\left({ }^{\circ} \mathrm{C}\right)$ & 451 & 451 & 452 \\
Feeding rate $(\mathrm{g} / \mathrm{h})$ & 275 & 271 & 275
\end{tabular}




\begin{tabular}{|c|c|c|c|}
\hline \multicolumn{4}{|l|}{ Yields (wt. daf \%) } \\
\hline Gas & 26.1 & 28.2 & 23.3 \\
\hline Char and coke & 13.3 & 13.2 & 13.5 \\
\hline Aqueous phase & 33.3 & 33.4 & 33.6 \\
\hline Organic phase & 17.7 & 16.5 & 20.0 \\
\hline $\mathrm{C}_{4+}$ in the gas & 7.5 & 7.8 & 6.4 \\
\hline Organics $+\mathrm{C}_{4+}$ & 25.2 & 24.3 & 26.4 \\
\hline Mass balance & 97.8 & 99.1 & 96.7 \\
\hline \multicolumn{4}{|l|}{ Carbon recovery (\%) } \\
\hline $\mathrm{C}_{1}-\mathrm{C}_{3}$ & 19 & 20 & 17 \\
\hline $\mathrm{C}_{4+}$ & 13 & 13 & 11 \\
\hline $\mathrm{CO}+\mathrm{CO}_{2}$ & 11 & 12 & 9.3 \\
\hline Char & $\mathrm{Na}$ & $\mathrm{Na}$ & $\mathrm{Na}$ \\
\hline Organic phase & 26 & 24 & 28 \\
\hline Aqueous phase & 3.2 & 2.8 & 4.2 \\
\hline $\mathrm{C}_{4+}+$ organic phase & 39 & 37 & 39 \\
\hline \multicolumn{4}{|c|}{ Organic phase composition } \\
\hline Water (wt.\%) & 3.3 & 2.6 & 4.1 \\
\hline$C(w t . \% d b)^{a}$ & 81 & 80 & 79 \\
\hline$H(w t . \% d b)$ & 9.39 & 9.44 & 9.26 \\
\hline $\mathrm{O}(\mathrm{wt} . \% \mathrm{db})$ & 9.0 & 10.2 & 11.7 \\
\hline$S(w t . \% d b)$ & 0.22 & 0.26 & 0.38 \\
\hline \multicolumn{4}{|l|}{ Organic phase density } \\
\hline Density at $40^{\circ} \mathrm{C}(\mathrm{g} / \mathrm{ml})$ & 0.9428 & 0.9396 & 0.9560 \\
\hline \multicolumn{4}{|c|}{ Aqueous phase carbon content } \\
\hline$C(w t . \%)$ & 4.3 & 3.7 & 5.6 \\
\hline \multicolumn{4}{|c|}{ Gas composition (wt.\% daf) } \\
\hline $\mathrm{CO}$ & 3.5 & 7.6 & 4.8 \\
\hline $\mathrm{CO}_{2}$ & 9.2 & 9.4 & 9.5 \\
\hline $\mathrm{C}_{1}-\mathrm{C}_{3}$ & 10.3 & 11.2 & 8.9 \\
\hline $\mathrm{C}_{4+}$ & 7.5 & 7.8 & 6.4 \\
\hline
\end{tabular}

\subsection{Product distribution}

The product distribution for three experiments using the CoMo, NiMo and Mo as catalysts at similar reaction conditions is shown in Figure 2. The combined char and coke yield varied between 13.2 and 13.5 wt.\% daf, which indicates that it is not influenced by the promoter. However, a significant difference in the total gas yield (between 23.3 and $28.2 \mathrm{wt} . \%$ daf) was observed. The $C_{1}-C_{3}$ yield varied between 8.9 and 11.2 wt.\% daf and was highest for the NiMo catalyst and lowest for the Mo catalyst. A similar trend was observed for the total $\mathrm{CO}$ and $\mathrm{CO}_{2}$ yield, which was 17.0 wt.\% daf for the NiMo, 15.8 wt.\% for the CoMo, and 14.4 wt.\% daf for the Mo. Interestingly, the $\mathrm{CO}_{2}$ yield was almost the same for all catalysts (9.2-9.5 wt.\% daf), thus the differences was due to changes in the CO yield (4.8-7.6 wt.\% daf), indicating differences in the catalyst's decarbonylation activity. However, the CO could also be formed through decarboxylation 
257 followed by reverse water gas shift. It can therefore be assumed that the NiMo catalyst has the highest 258 decarbonylation/decarboxylation activity.

The $\mathrm{C}_{2}-\mathrm{C}_{3}$ paraffins yield for the NiMo catalyst ( $4.6 \mathrm{wt}$.\% daf) was significantly higher than for the CoMo (3.1 wt.\% daf), and Mo (2.8 wt.\% daf), while the olefins yield was lower for the NiMo catalyst (2.6 wt.\% daf)

14261 than for the CoMo (3.6 wt.\% daf) and Mo catalyst (3.1 wt.\% daf), see supporting information Figure S.4.

Thus the paraffins to olefins ratio was 1.8 for the NiMo, but 0.90 for both the CoMo and Mo catalysts, showing that the NiMo catalyst had the highest hydrogenation activity, which is in agreement with experiments using 2-ethylphenol as a model components at significantly lower temperatures $\left(340^{\circ} \mathrm{C}\right)$ and higher pressures (70 bar) ${ }^{25}$.

The aqueous phase yield varied between 33.3 and 33.6 wt.\% daf, which is the same for all catalysts within the experimental uncertainty. The highest observed condensable organics yield was $26.4 \mathrm{wt} . \%$ daf for the Mo and the lowest was 24.3 wt.\% daf for the NiMo. Thus, an inverse relationship between the gas yield and condensable organics yield was observed, as opposed to our previous study where the temperature in the fluid bed reactor was varied and an inverse relationship between the gas and char yield was observed ${ }^{29}$. 271 This shows that the char yield is mainly influenced by the process conditions ${ }^{29}$ and the condensable organic 272 yield is mainly influenced by the catalyst properties, while the gas yield is very dependent on both the process conditions and the catalyst properties. 


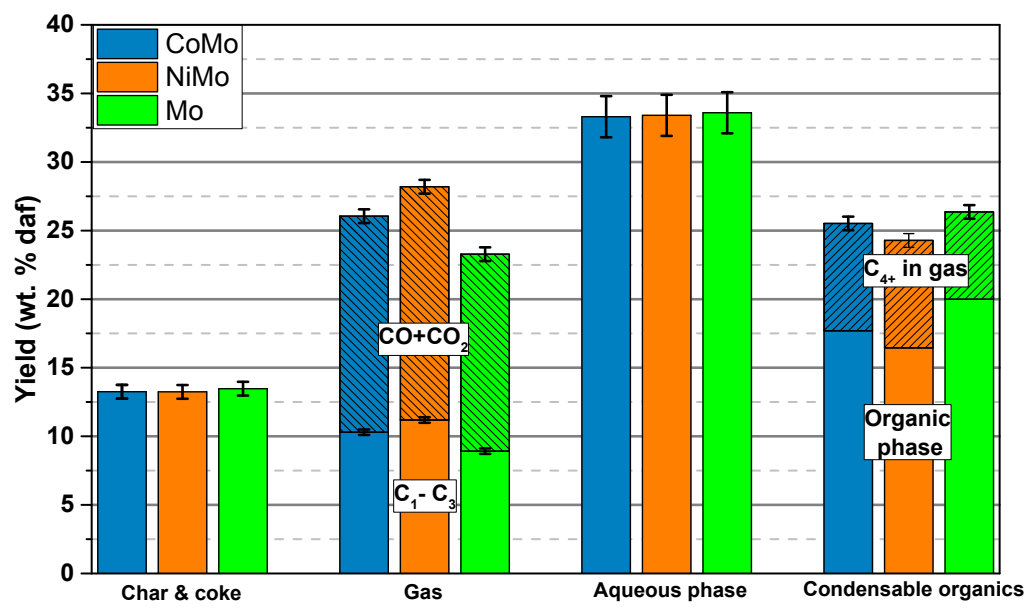

Figure 2 Product distribution for catalytic hydrolysis of beech wood using sulfided CoMo, NiMo and Mo as catalyst. Conditions: Fluid bed temperature: $451-452^{\circ} \mathrm{C}$, total pressure: 26 bar, biomass feeding rate: $271-275 \mathrm{~g} / \mathrm{h}$, biomass used: $946-964 \mathrm{~g}, \mathrm{H}_{2}$ flow: $82 \mathrm{NL} / \mathrm{min}, \mathrm{N}_{2}$ flow: $5 \mathrm{NL} / \mathrm{min}$, and $\mathrm{H}_{2} \mathrm{~S}$ conc: $460 \mathrm{ppm}$.

The difference between sulfided CoMo, NiMo and Mo supported on $\mathrm{MgAl}_{2} \mathrm{O}_{4}$ has also been studied for HDO of ethylene glycol, a model compound for aliphatic oxygenates formed during pyrolysis of cellulose and hemicellulose, in a continuous flow setup by our group ${ }^{17}$. It was observed that Mo had the lowest cracking activity, based on the lower yields of $\mathrm{CO}, \mathrm{CO}_{2}$ and $\mathrm{CH}_{4}$, but that the cracking activities of the CoMo and NiMo were similar. The difference in the relative cracking activity for the CoMo and NiMo catalysts in this study and the study on ethylene glycol as model compound for $\mathrm{HDO}^{17}$ was probably because ethylene glycol is a simple molecule, while the real biomass used here is significantly more complex. Laurent et al. ${ }^{34}$ also studied the difference between sulfided CoMo and NiMo catalyst for HDO of pyrolysis oil model compounds in a batch reactor and found that the NiMo catalysts had the highest decarboxylation activity. Krause et al. ${ }^{12-16}$ studied the hydrodeoxygenation of different model compounds with sulfided CoMo and NiMo catalysts. They also found that the NiMo catalyst had the highest hydrogenation activity and carboxylation/carbonylation activity. Thus the results obtained in this study are in agreement with the HDO literature.

The $\mathrm{CO}$ to $\mathrm{CO}_{2}$ molar ratio for the CoMo was 1.1 , while in our previous hydropyrolysis study, where a commercial CoMo/ $\mathrm{MgAl}_{2} \mathrm{O}_{4}$ was used in the fluid bed reactor, the $\mathrm{CO}$ to $\mathrm{CO}_{2}$ molar ratio was $3.1^{29}$. However, the commercial CoMo/ $\mathrm{MgAl}_{2} \mathrm{O}_{4}$ had a higher activity, the oxygen content in the condensed 
organic phase was only 1.8 wt.\%, compared to 9.0 wt.\% for the CoMo catalyst tested in this study. Thus, the difference in $\mathrm{CO}$ to $\mathrm{CO}_{2}$ ratio is most likely because the more active commercial catalyst also catalyzed

\subsection{Chemical composition of the condensed liquids}

The chemical composition of the condensed organic phases is shown in Table 2 . The oxygen content in the condensed organic phase for the CoMo catalyst was 9.0 wt.\% db, 10 wt.\% db for the NiMo, and 12 wt.\% db for the Mo catalyst, thus indicating that the deoxygenation activity of the catalysts followed the trend: CoMo>NiMo>Mo. The carbon efficiency for the $\mathrm{C}_{4+}$ organics is $39 \%$ for both the CoMo and the Mo, but only $37 \%$ for the NiMo, thus the trend for the carbon efficiency is: CoMo $\approx$ Mo>NiMo. Furthermore, since the oxygen content in the produced organics is lower for the CoMo compared to the Mo, the CoMo catalyst is considered to be favorable.

The organic phase from the experiment with the NiMo catalyst had a slightly higher hydrogen content (9.44 wt.\% db), than the CoMo (9.39 wt.\% db) and Mo (9.26 wt.\% db), however the difference is within the experimental uncertainty. The density of the organic phase was also lower using the NiMo (0.9396 g/ml), compared to when the CoMo $(0.9428 \mathrm{~g} / \mathrm{ml})$ and the Mo $(0.9560 \mathrm{~g} / \mathrm{ml})$ were used. The lower density is most likely due to the observed cracking activity for the NiMo.

The sulfur content in the condensed organics, when the Mo catalyst was used, was 0.38 wt.\% db, which is significantly higher than when the CoMo (0.22 wt.\% db) and the NiMo (0.26 wt.\% db) were used. Since the beech wood only contained 43 wt.-ppm S most of the sulfur in the organic phase must come from incorporation of $\mathrm{S}$ from the $\mathrm{H}_{2} \mathrm{~S}$ in the gas phase, through the activity of the sulfided catalysts. In order to obtain a better understanding of the sulfur containing species in the condensed organics, the samples were analyzed with sulfur specific GC-AED, see Figure 3 (a detailed list of the detected compounds is shown in supporting information tables S.4-S.6). This showed that there was between 382 and $572 \mathrm{ppm} \mathrm{H}_{2} \mathrm{~S}$ dissolved in the samples, despite the $\mathrm{N}_{2}$ stripping procedure employed. The main sulfur containing 
molecules identified in the organic phase were thiols, thiophenes, and benzothiophenes, including 319 dibenzothiophenes. Methyl-ethylsulfide and dimethyl disulfide (DMDS) were also detected in the organic phase, but a large fraction of the sulfur compounds was not identified. Since the applied temperature in the fluid bed reactor is close to the temperature used in fluid catalytic cracking (FCC $)^{35,36}$, it is possible that the sulfur from the $\mathrm{H}_{2} \mathrm{~S}$ is incorporated into the organics by similar reactions routes as in FCC. The concentration of thiophenes was significantly higher from the experiment with the Mo catalyst, Figure 3, than from the experiments with the CoMo, and NiMo indicating that hydrodesulfurization also takes place in the fluid bed reactor. The concentration of thiols was 23 wt-ppm S when the NiMo catalyst was used and 55 and 88 wt-ppm S when the CoMo and Mo was used, respectively. This is probably because of the higher hydrogenation activity of the NiMo catalyst, which decreased the concentration of olefins, thus minimizing the incorporation of $\mathrm{H}_{2} \mathrm{~S}$ through recombination between olefins and $\mathrm{H}_{2} \mathrm{~S}^{37-40}$. Alternatively the thiols could have been formed from the alcohols through a nucleophilic substitution ${ }^{12,16}$. It should be noted that in order to minimize the cracking activity, the HDO and HDS activity for these catalysts were purposely fairly low, which is part of the reason for the high sulfur content in the condensed organics. In our previous work we showed that it is possible to reduce the sulfur content in the organic phase to $0.06 \mathrm{wt} . \%$ by using a second HDO reactor ${ }^{29}$. Since sulfur compounds are commonly encountered in petrochemical refining and removed by hydrotreating the high sulfur concentration is of minor concern. 


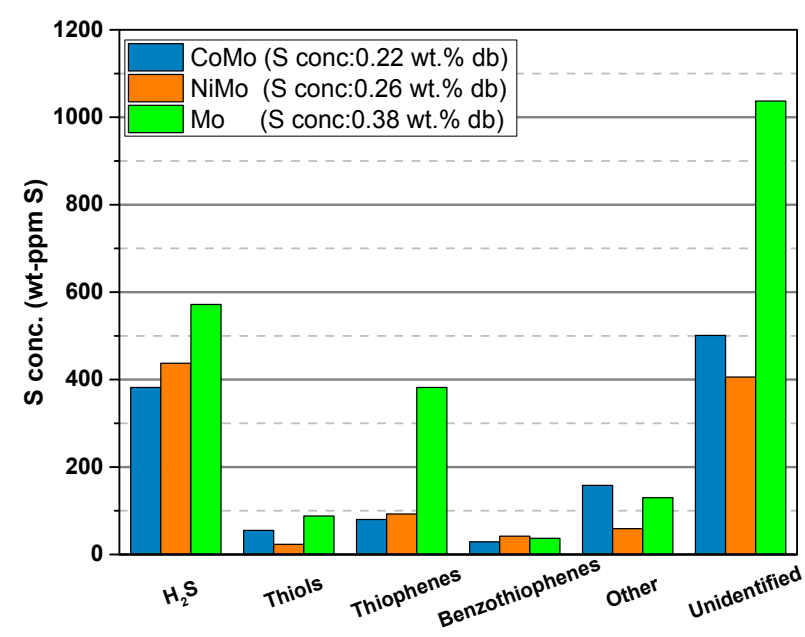

Figure 3 Concentration of sulfur species in the condensed organic phase from experiments with the CoMo, NiMo, and Mo catalyst analyzed with S specific GC-AED. Conditions: Fluid bed temperature: $451-452^{\circ} \mathrm{C}$, pressure: 26 bar, biomass feeding rate: 271-275 g/h, biomass used: 946-964 g, $\mathrm{H}_{2}$ flow: $82 \mathrm{NL} / \mathrm{min}, \mathrm{N}_{2}$ flow: $5 \mathrm{NL} / \mathrm{min}$, and $\mathrm{H}_{2} \mathrm{~S}$ conc: $460 \mathrm{ppm}$.

The composition of the condensed organic phases was studied with GCXGC-ToF/MS or -FID and concentrations of paraffins (Par), naphthenes (Naph), monoaromatics (mAro), diaromatics (diAro), triaromatics (triAro), and larger aromatics (tetAro+), oxygenated aliphatics (O-Ali), phenols (PhOH), dihydroxybenzenes $(\mathrm{Ph}(\mathrm{OH}) 2$ ) and oxygenated di- and larger aromatics (O-Aro) were measured, see Figure 4. Comparing the CoMo, Figure 4A, with the NiMo, Figure 4B, the concentration of paraffins, naphthenes, and oxygenated aliphatics are almost the same. However, the concentration of diaromatics and larger aromatics were $16 \%$ for the CoMo and $13 \%$ for the NiMo. This is most likely because the NiMo catalyst mainly removes oxygen (and sulfur) by first hydrogenating the aromatic ring and then removing the oxygen (HYD pathway) ${ }^{25,28}$, while the CoMo catalyst removes the oxygen without first hydrogenating the ring (DDO pathway) ${ }^{18,25-27}$. At the applied reaction conditions the monoaromatics-naphthenes equilibrium is shifted towards aromatics ${ }^{29}$, which makes it more difficult for the NiMo catalyst to remove the oxygen resulting in a slightly higher phenols yield. Thus, the lower concentration of di- and larger aromatics and higher concentration of monoaromatics and phenols for the NiMo catalyst is probably due to its higher hydrogenation activity, since hydrogenation of di- and higher aromatics is not equilibrium limited. Furthermore, the number of carbon atoms in the molecules is lower for the NiMo than the CoMo catalyst, due to its higher cracking activity. 

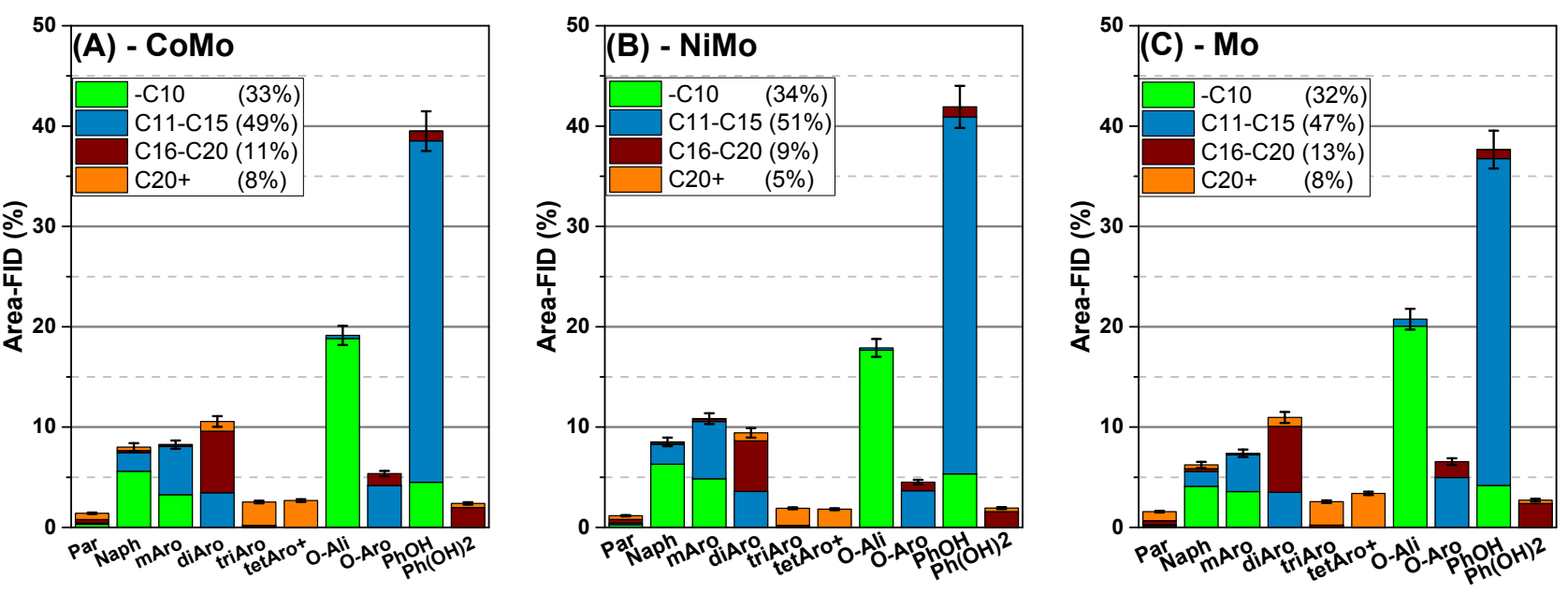

Figure 4 The composition of the condensed organic phases using the CoMo catalyst (A), the NiMo catalyst (B), and the Mo catalyst (C). Conditions: Fluid bed temperature: $451-452^{\circ} \mathrm{C}$, pressure: $26 \mathrm{bar}$, biomass feeding rate: $271-275 \mathrm{~g} / \mathrm{h}$, biomass used: 946-964 g, $\mathrm{H}_{2}$ flow: $82 \mathrm{NL} / \mathrm{min}, \mathrm{N}_{2}$ flow: $5 \mathrm{NL} / \mathrm{min}$, and $\mathrm{H}_{2} \mathrm{~S}$ conc: $460 \mathrm{ppm}$.

The organic phase from the experiment with the Mo catalyst, Figure $4 C$, contains more oxygenated aliphatics (21 \%) than for the CoMo (19\%) and NiMo (18\%) catalysts. This indicates that Mo has a lower HDO activity than the CoMo and NiMo, as expected. The concentration of phenols is lowest for the Mo, however, this could be due to a higher concentration of other oxygenated hydrocarbons, which decreases the relative FID-area for the phenols. The lower concentration of naphthenes shows that the Mo has the lowest hydrogenation activity. Traces $(<0.2 \%$ area-FID) of sterols were detected in all the condensed organic phases.

In fast pyrolysis it is generally assumed that the aromatics and phenols comes from the lignin in the biomass, while the heterocyclic compounds such as furans and sugars originates from cellulose and hemicellulose ${ }^{41}$. The high concentration of aromatics and phenols (approximately $65 \%$-area FID) in the condensed organic phase indicates that it mostly originates from the lignin fraction of the biomass. However, tests with pure cellulose, hemicellulose and lignin are needed to support this hypothesis.

The carbon recovery and the composition of the aqueous phases are shown in Table 2 . The carbon recovery in the aqueous phase was $2.8 \%$ for the NiMo catalyst and $3.2 \%$ for the CoMo catalyst, which is not a significant difference. The higher carbon recovery for Mo $(4.2 \%)$ in the aqueous phase is probably due to the higher oxygen content in the organic phase which makes it more miscible with water. 


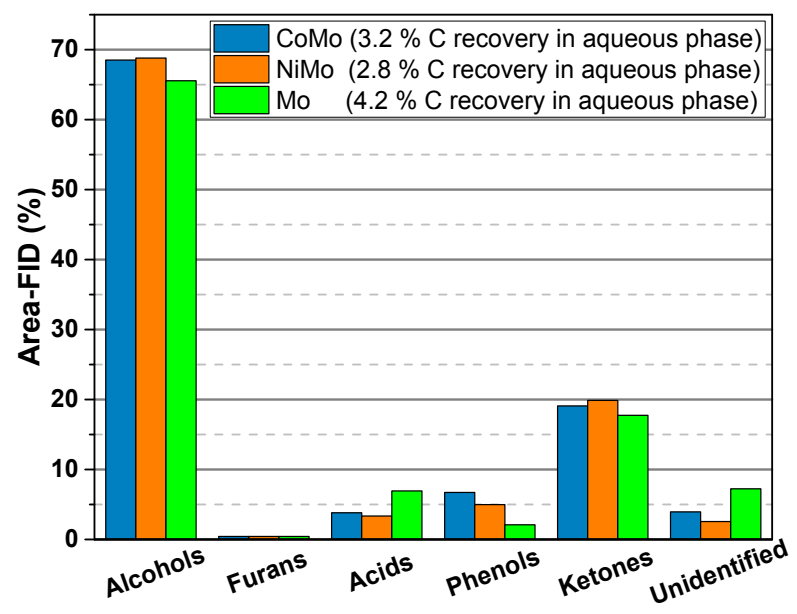

Figure 5 Composition of the aqueous phase when the CoMo (A), NiMo (C), and Mo(C) catalyst was used. Conditions: Fluid bed temperature: $451-452^{\circ} \mathrm{C}$, pressure: 26 bar, biomass feeding rate: $271-275 \mathrm{~g} / \mathrm{h}$, biomass used: $946-964 \mathrm{~g}, \mathrm{H}_{2}$ flow: $82 \mathrm{NL} / \mathrm{min}, \mathrm{N}_{2}$ flow: $5 \mathrm{NL} / \mathrm{min}$, and $\mathrm{H}_{2} \mathrm{~S}$ conc: $460 \mathrm{ppm}$.

The composition of the aqueous phases was similar for the three catalysts, see Figure 5 . It mainly consisted of alcohols (66-69\%), which was mostly methanol and ethanol (see supporting information tables S.7-S.9), and ketones (18-20\%) in the $C_{2}-C_{5}$ range. The amount of phenol was between 2.1 and $6.7 \%$, the amount of furans was $0.43 \%$ independent of the type of catalyst, and the amount of acids was $6.9 \%$ for the Mo, but only 3.3 and $3.8 \%$ for the NiMo and the CoMo, respectively. Acetic acid was the only acid or ester detected in the aqueous phase in the experiment with the NiMo and CoMo, while butyl formate was also observed for the Mo. The observed acetic acid indicate, that if catalytic hydropyrolysis is conducted without the additional HDO reactor, the downstream equipment should be acid resistant. Dabros ${ }^{42}$ tested hydrodeoxygenation of acetic acid over a NiMo catalyst and observed plugging above the catalyst bed after $2 \mathrm{~h}$ on stream due to coke formation. Therefore, it would be desirable to remove as much of the acetic acid as possible during the initial catalytic hydropyrolysis step.

\subsection{Characterization of the catalysts}

\subsubsection{Raman spectroscopy of the calcined oxide catalyst precursors}

Raman spectroscopy was used in order to determine the phases and dispersion for the oxide precursors, see Figure 6. Three spectra were recorded for each sample at different spots. The slight variations between the spectra for the same catalyst sample indicate some degree of heterogeneity. For the CoMo catalyst the 
bands for the carrier $\mathrm{MgAl}_{2} \mathrm{O}_{4}$ are observed at 760, 673 and $405 \mathrm{~cm}^{-1}$. The peak observed close to $872 \mathrm{~cm}^{-1}$ 396 can be assigned to hydrated $\mathrm{CoMoO}_{4}$ and would represent a Mo-O distance of $1.75 \AA$, according to the observed relationship for Mo-O stretching frequencies and bond distances proposed by Hardcastle and Wachs ${ }^{43}$. This could be a Mo-O-X ( $X=$ carrier or active metal) entity. The broad convoluted peak observed at 923-945 $\mathrm{cm}^{-1}$ in all the samples corresponds to a Mo-O distance of around $1.7 \AA$ and could come from terminal $\mathrm{Mo}=\mathrm{O}$ units. The presence of crystalline $\mathrm{MoO}_{3}$, which exhibit a sharp $\mathrm{Mo}=\mathrm{O}$ stretching mode at $992 \mathrm{~cm}^{-1}$, can be ruled out and thus the peak assembly probably originated from hydrated, amorphous $\mathrm{MoO}_{\mathrm{x}}$ phases ${ }^{44}$. Dabros et al. ${ }^{17}$ observed peaks at 315 and $910 \mathrm{~cm}^{-1}$ and assigned them to tetrahedral monomolybdate, thus the observed peak at 320 and $923-945 \mathrm{~cm}^{-1}$ could be this species. The monolayer coverage of $\mathrm{Mo}$ on $\mathrm{Al}_{2} \mathrm{O}_{3}$ is around $4.5 \mathrm{Mo} / \mathrm{nm}^{24}$, which means that these samples exhibit around $80 \%$ of a monolayer coverage. Therefore, some interaction between molybdenum oxide species would be expected and the existence of truly isolated sites is not likely. Since the $\mathrm{MgAl}_{2} \mathrm{O}_{4}$ phase is quite porous, capillary condensation of water inside the pores is likely to occur, and the observed species are probably mixtures of e.g. $\mathrm{MoO}_{4}{ }^{2-}(\mathrm{aq})$ (isolated, tetrahedral), $\mathrm{Mo}_{7} \mathrm{O}_{24}{ }^{6-}$ and $\mathrm{Mo}_{8} \mathrm{O}_{26}{ }^{4}$ (aq) (the two latter both polymerized octahedral) dissolved in the ambient air exposed calcined samples. $\mathrm{MoO}_{4}{ }^{2-}$ would contribute at 897,837 and $317 \mathrm{~cm}^{-1}, \mathrm{Mo}_{7} \mathrm{O}_{24}{ }^{6-}$ at $943,903,570,362$ and $210 \mathrm{~cm}^{-1}$, while $\mathrm{Mo}_{8} \mathrm{O}_{26}{ }^{4-}$ at $965,925,590,370$ and $230 \mathrm{~cm}^{-1}$ 44,45. Given the relatively high $\mathrm{MoO}_{\mathrm{x}}$ surface density combined with the major contributions of the $940-960$ $\mathrm{cm}^{-1}$ features it seems likely that the observed species are hydrated pre-cursors for polymeric molybdenum oxides. $\mathrm{CO}_{3} \mathrm{O}_{4}$ would have its major contribution at $692 \mathrm{~cm}^{-1}$, which is not observed, which indicates that $\mathrm{Co}$ is mainly present as hydrated $\mathrm{CoMoO}_{4}$.

For the NiMo catalyst the $954 \mathrm{~cm}^{-1}$ band coincides with $\alpha-N i M o O 4$ and the $878 \mathrm{~cm}^{-1}$ band with its hydrated form. No obvious peaks of crystalline $\mathrm{MoO}_{3}\left(992,820,667 \mathrm{~cm}^{-1}\right)$ were observed. However, it is possible that the peak at 326 and $954 \mathrm{~cm}^{-1}$ is due to a mixture of the previously mentioned hydrated molybdates. No pure $\mathrm{Ni}$ oxide phase was observed, indicating that the $\mathrm{Ni}$ was located as $\mathrm{NiMoO}_{4}$. This indicates that $\mathrm{Ni}$ after the sulfidation is located in the so-called NiMoS phase ${ }^{24}$ and not the less active $\mathrm{NiS}_{\mathrm{x}}$ phase $\mathrm{e}^{17}$. The bands 
420 observed at 316 and $957 \mathrm{~cm}^{-1}$ for the Mo catalyst can be assigned to a hydrated $\mathrm{MoO}_{\mathrm{x}}$ phase and again no 421 peaks of crystalline $\mathrm{MoO}_{3}\left(992,820,667 \mathrm{~cm}^{-1}\right)$ were observed.

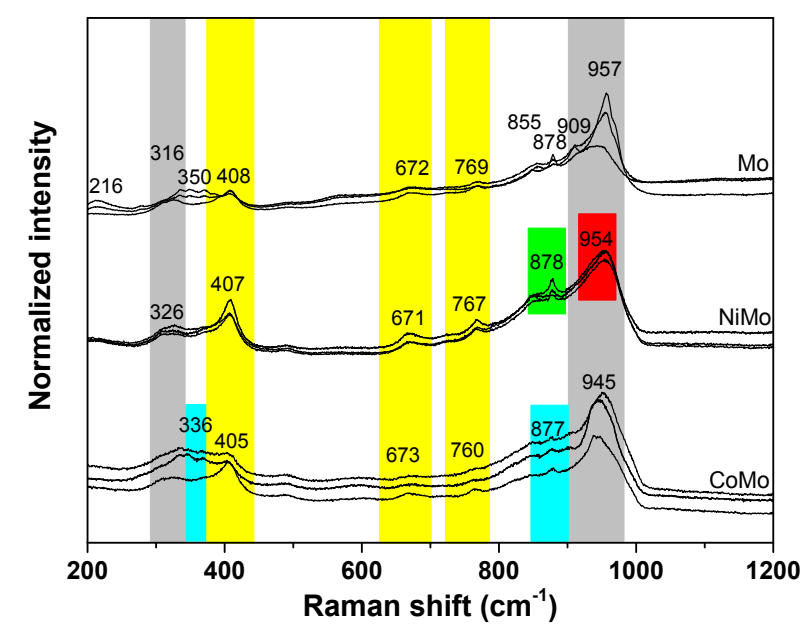

Figure 6 Baseline corrected Raman spectra of CoMo, NiMo, and Mo in the oxide phase (calcined, not dehydrated). The Raman bands were assigned to hydrated, $\mathrm{MoO}_{x}$ (gray), hydrated $\mathrm{CoMoO}_{4}$ (cyan), alfa $\mathrm{NiMoO}_{4}$ (red), hydrated $\mathrm{NiMoO}_{4}$ (green), and $\mathrm{MgAl}_{2} \mathrm{O}_{4}$ (yellow).

\subsubsection{Characterization of the spent catalysts}

The carbon and potassium contents on the spent and fresh catalysts were measured with SEM combined with EDS. In order to account for the carbon signal from the carbon tabs the actual carbon content on the catalysts were calculated by subtracting the measured carbon content on the fresh catalysts from the measured carbon content on the spent catalysts, and the results is shown as a function of the acceleration voltage in Figure 7. With increased acceleration voltage the electron beam penetrates slightly deeper into the sample, therefore at low acceleration voltages $(3 \mathrm{kV})$ the surface concentration on the catalyst particles is measured, while at high acceleration voltages $(15 \mathrm{kV})$ the concentration slightly into the particle is measured. The estimated interaction depth ranges from 170 to $1600 \mathrm{~nm}$ with acceleration voltage between 3 and $15 \mathrm{kV}$, respectively, see Table S.2. Due to the relatively high molar mass of potassium it is not possible to excite its core electrons at $3 \mathrm{kV}\left(\mathrm{K}-\mathrm{K}_{\alpha}\right.$ line at $\left.3.31 \mathrm{keV}\right)$. The carbon content on the spent Mo catalyst was between 5.0 and 5.5 wt.\%, while it was between 0.9 and 3.3 wt.\% for the spent CoMo and NiMo catalysts

(Figure 7A), showing that the lower hydrodeoxygenation activity for the Mo catalyst lead to an increased degree of coking. The carbon content on the spent NiMo and CoMo decreased with increasing accelerating 
voltage, showing that more coke was located at the surface of the catalysts. The potassium content on the spent catalysts (Figure 7B), was between 0.3 (in the bulk) and 2.4 wt.\% (at the surface) and no significant
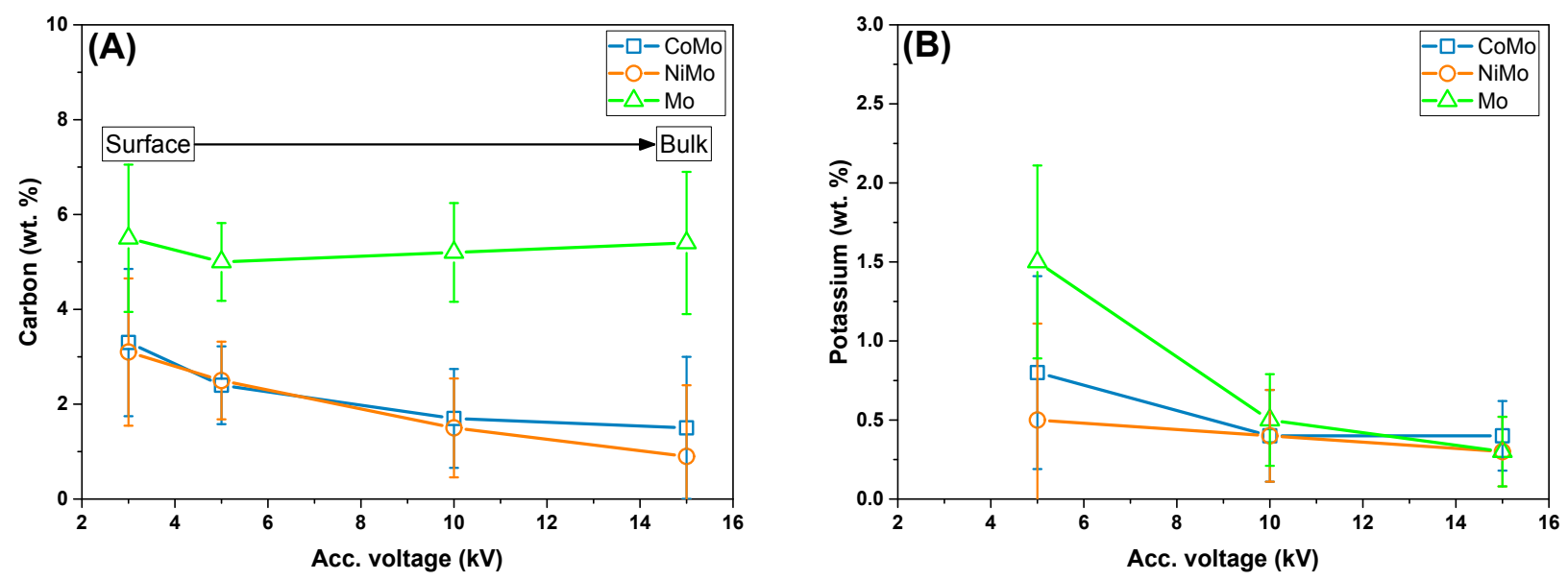

Figure 7 Carbon (A) and potassium (B) content on the spent measured with SEM combined with EDS. The carbon and potassium for the fresh and spent catalysts are shown in supporting information Table S.10. Conditions: Fluid bed temperature: $451-452^{\circ} \mathrm{C}$, pressure: 26 bar, biomass feeding rate: 271-275 g/h, biomass used: 946-964 g, $\mathrm{H}_{2}$ flow: $82 \mathrm{NL} / \mathrm{min}, \mathrm{N}_{2}$ flow: $5 \mathrm{NL} / \mathrm{min}$, and $\mathrm{H}_{2} \mathrm{~S}$ conc: $460 \mathrm{ppm}$.

Figure 8 shows HAADF-STEM images of the spent CoMo, NiMo, and Mo catalysts and reveal nanometersized slab structures of bright contrast distributed on the surface of larger support grains (about 10-30 nm in size) of less image contrast. Occasionally, the slab structures were found with 2 or more layers (up to 4) stacked with an interlayer-distance of $0.62 \mathrm{~nm}$, consistent with a $\mathrm{MoS}_{2}$ (001) spacing (Figure 8A). The bright-contrasted slab structures are therefore attributed to single, double- or multilayer layer $\mathrm{MoS}_{2}$ nanocrystals viewed with the (001) basal plane along the electron beam direction, and situated with the basal plane along the surfaces of the larger $\mathrm{MgAl}_{2} \mathrm{O}_{4}$ grains, as previously reported ${ }^{47}$. Based on 10 images per catalyst, and measuring between 111 and 128 slabs per sample, the MoS $_{2}$ nanocrystals were 
predominantly found as single layer structures (>98\%), and the slab lengths were measured (Figure 8E-F).

The slab lengths were between 1 and $5.5 \mathrm{~nm}$ with an average between 2.8 and $2.9 \mathrm{~nm}$ for all the catalysts.

Thus the slab size and distribution was similar for all the spent catalysts, which indicates that the $\mathrm{MoS}_{2}$ edge dispersions of the tested catalysts were comparable. Furthermore, the single layer structure indicates that the catalysts were in the less active type I CoMoS phase ${ }^{31}$, which together with their low loading is the reason for their relatively low activity.
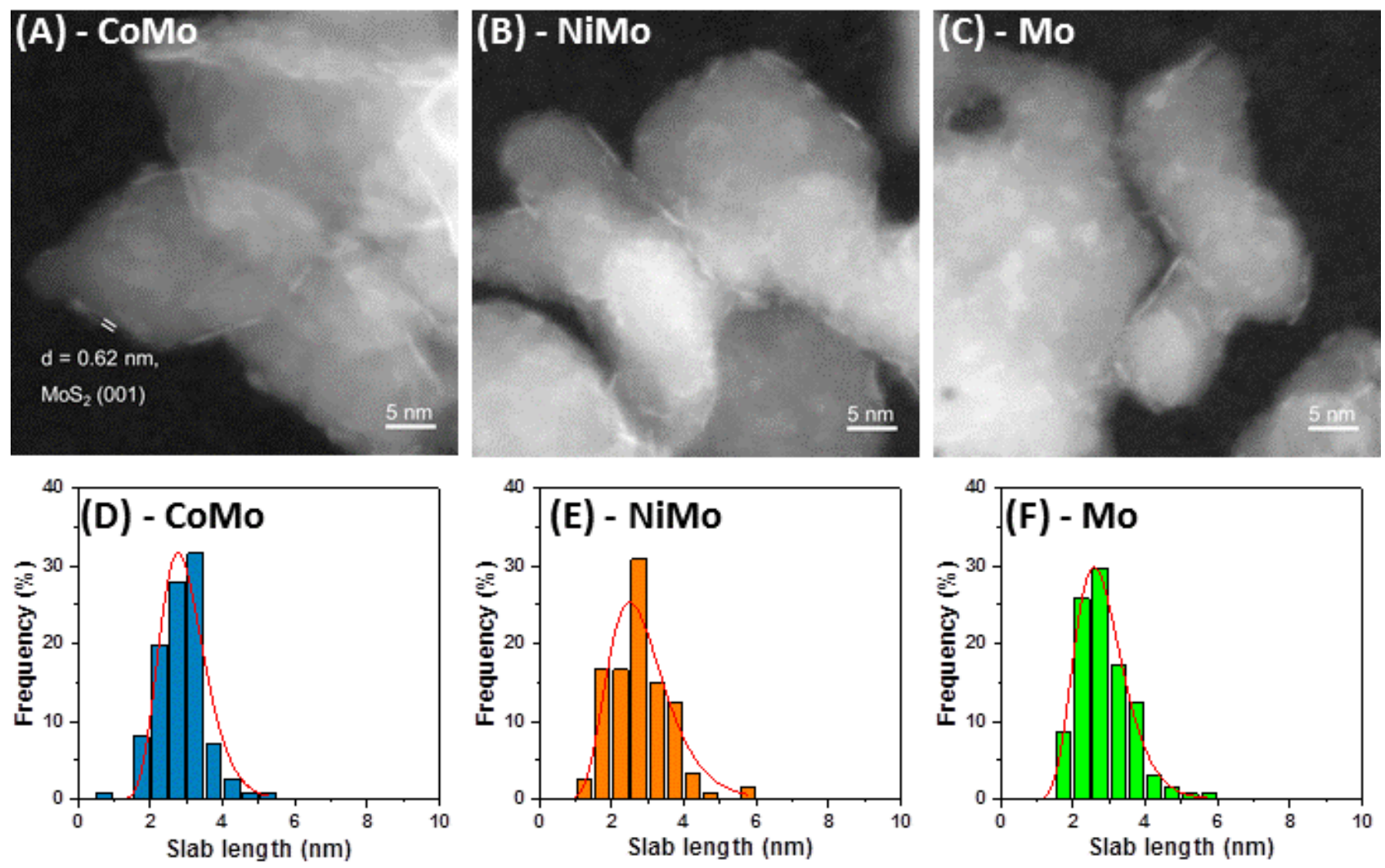

Figure 8 HAADF-STEM images of CoMo (A), NiMo (B), and Mo (C), and single layer slab size distribution of CoMo (D), NiMo (E), and $\mathrm{Mo}(\mathrm{F})$. The images in (A)-(C) were contrast adjusted (gamma) to improve visibility. Conditions: Fluid bed temperature: 451$452^{\circ} \mathrm{C}$, pressure: 26 bar, biomass feeding rate: $271-275 \mathrm{~g} / \mathrm{h}$, biomass used: $946-964 \mathrm{~g}, \mathrm{H}_{2}$ flow: $82 \mathrm{NL} / \mathrm{min}, \mathrm{N}_{2}$ flow: $5 \mathrm{NL} / \mathrm{min}$, and $\mathrm{H}_{2} \mathrm{~S}$ conc: $460 \mathrm{ppm}$.

The distribution of the promoter, molybdenum and sulfur on the spent catalysts is shown on the elemental maps in Figure 9 (For single element EDS maps see supporting material Figures S.6-S.8). The molybdenum (and sulfur) is well distributed on the $\mathrm{MgAl}_{2} \mathrm{O}_{4}$ support for the three catalysts, consistent with a uniform and high degree of $\mathrm{MoS}_{2}$ dispersion (Figure 8). Furthermore, the promoter (Co/Ni) is also highly dispersed and mainly located the same places as molybdenum, as shown in Figure 9B and Figure 9E, suggesting 

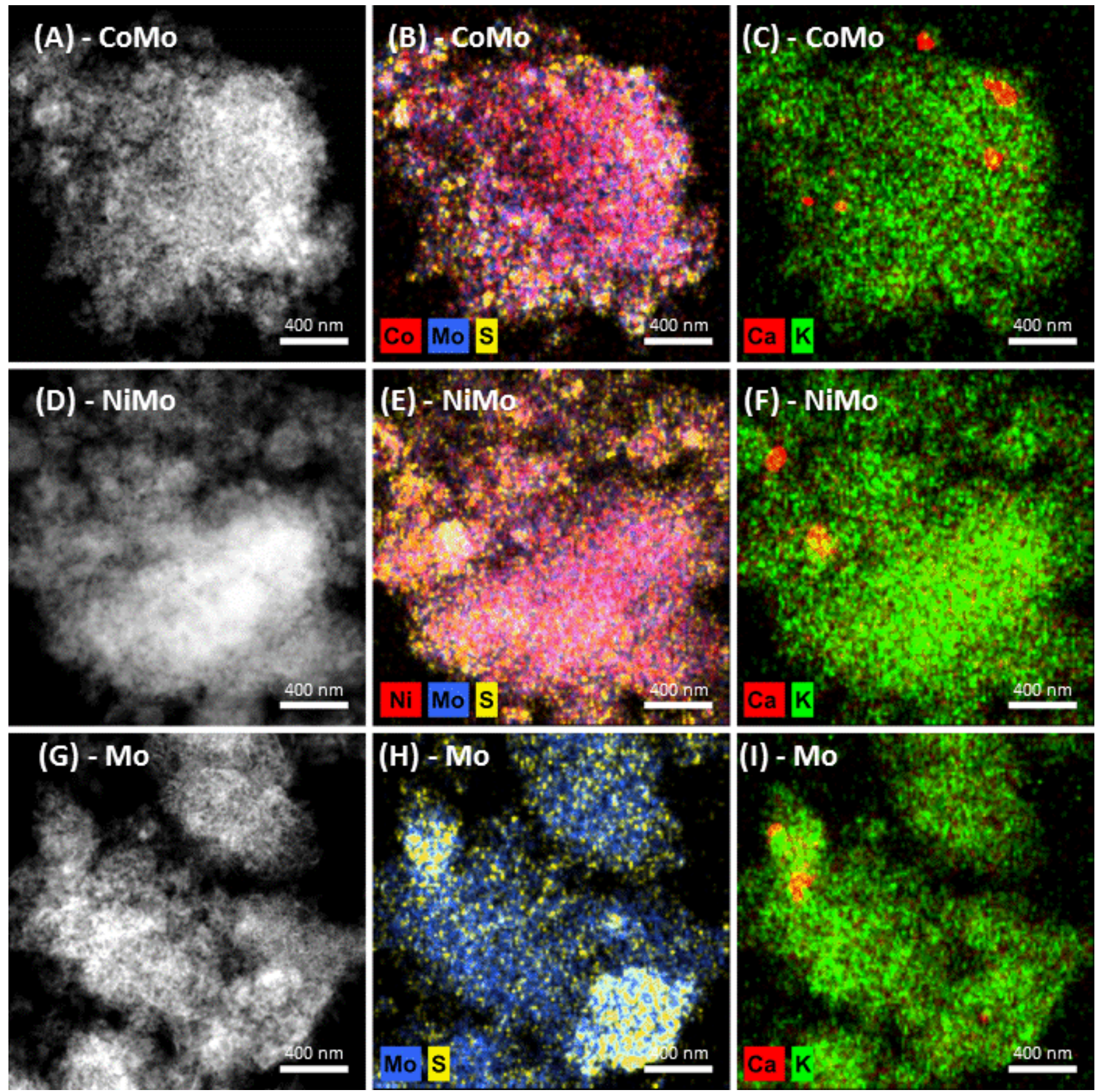

Figure 9 STEM-HAADF micrograph of molybdenum, cobalt, sulfur, potassium, and calcium EDS element distribution on CoMo (AC), molybdenum, nickel, sulfur, potassium and calcium EDS element distribution on NiMo (D-F), and molybdenum, sulfur, potassium and calcium EDS element distribution on Mo (G-I). Conditions: Fluid bed temperature: $451-452^{\circ} \mathrm{C}$, pressure: 26 bar, biomass feeding rate: $271-275 \mathrm{~g} / \mathrm{h}$, biomass used: $946-964 \mathrm{~g}, \mathrm{H}_{2}$ flow: $82 \mathrm{NL} / \mathrm{min}, \mathrm{N}_{2}$ flow: $5 \mathrm{NL} / \mathrm{min}$, and $\mathrm{H}_{2} \mathrm{~S}$ conc: $460 \mathrm{ppm}$. 


\section{Conclusion}

Catalytic hydropyrolysis of beech wood was conducted in a fluid bed reactor at $450^{\circ} \mathrm{C}$ and 26 bar with three different sulfided catalysts: CoMo/ $\mathrm{MgAl}_{2} \mathrm{O}_{4}, \mathrm{NiMo} / \mathrm{MgAl}_{2} \mathrm{O}_{4}$, and $\mathrm{Mo} / \mathrm{MgAl}_{2} \mathrm{O}_{4}$. $\mathrm{BET}$ surface area, elemental analysis, Raman spectroscopy and STEM images of the spent catalysts showed that the three catalysts had similar morphology and a comparable metal content, therefore the influence of the promoters on catalytic activity and selectivity could be investigated. The char and aqueous phase yields were not affected by the applied promoter type. The $\mathrm{NiMo} / \mathrm{MgAl}_{2} \mathrm{O}_{4}$ catalyst had the highest cracking, decarbonylation/decarboxylation, and hydrogenation activity, while the $\mathrm{Mo} / \mathrm{MgAl}_{2} \mathrm{O}_{4}$ catalyst had the lowest. The highest condensed organics and $\mathrm{C}_{4+}$ yield was obtained with the $\mathrm{Mo} / \mathrm{MgAl}_{2} \mathrm{O}_{4}$ (26.4 wt.\% daf) and the lowest with the $\mathrm{NiMo} / \mathrm{MgAl}_{2} \mathrm{O}_{4}$ (24.3 wt.\% daf). However, the organic phase from the experiment with the $\mathrm{Mo} / \mathrm{MgAl}_{2} \mathrm{O}_{4}$ had an oxygen content of $12 \mathrm{wt} \% \mathrm{db}$, while it was $10 \mathrm{wt} \% \mathrm{db}$ and 9.0 wt.\% db when the $\mathrm{NiMo} / \mathrm{MgAl}_{2} \mathrm{O}_{4}$ and CoMo/MgAl2O4 were used, respectively. This difference, was ascribed to the main reaction pathway, hydrogenation for the NiMo and direct deoxygenation for the CoMo, for the deoxygenation of phenols. The carbon recovery $\left(\mathrm{C}_{4+}\right.$ and condensed organics) was $39 \%$ for both the CoMo/ $/ \mathrm{MgAl}_{2} \mathrm{O}_{4}$ and $\mathrm{Mo} / \mathrm{MgAl}_{2} \mathrm{O}_{4}$, but $37 \%$ for the $\mathrm{NiMo} / \mathrm{MgAl}_{2} \mathrm{O}_{4}$. Therefore, this study indicates that CoMo/ $\mathrm{MgAl}_{2} \mathrm{O}_{4}$ is favorable for use in catalytic hydropyrolysis compared to $\mathrm{NiMo} / \mathrm{MgAl}_{2} \mathrm{O}_{4}$ and $\mathrm{Mo} / \mathrm{MgAl}_{2} \mathrm{O}_{4}$

The carbon content on the spent $\mathrm{Mo} / \mathrm{MgAl}_{2} \mathrm{O}_{4}$ catalyst was higher than on the $\mathrm{CoMo} / \mathrm{MgAl}_{2} \mathrm{O}_{4}$ and $\mathrm{NiMo} / \mathrm{MgAl}_{2} \mathrm{O}_{4}$, which was probably because of its lower activity, which increased the degree of coking. Calcium and potassium were transferred from the biomass ash to the catalysts under reaction conditions. Calcium was observed as larger $(40-200 \mathrm{~nm})$ single particles, which only had a minor impact on the catalytic activity. Potassium was highly dispersed on the catalyst particles, which has potentially decreased the catalytic activity. The transfer of alkali metals from the biomass to the catalyst could be a serious problem in full scale applications, and should be further investigated in order to better understand how the alkali 

515 laboratories. catalysts

metals are transferred and their effect on the catalytic activity. Such investigations are on-going in our

\section{Associated content}

\subsection{Supporting information}

$\mathrm{NH}_{3}$-TPD of the calcined oxide catalyst precursors; estimated penetration depth for electron beam in $\mathrm{MgAl}_{2} \mathrm{O}_{4}$; detailed gas composition; equilibrium calculations; overview of sulfur containing molecules detected with sulfur specific GC-AED and hydrocarbons detected in the aqueous phase; carbon and potassium content on the calcined oxide catalyst precursors; elemental maps (STEM-EDS) of the spent

\section{Acknowledgments}

This work is part of the project "Hydrogen assisted catalytic pyrolysis for green fuels" conducted at The Department of Chemical and Biochemical Engineering at the Technical University of Denmark (DTU). The work was supported by The Danish Council for Strategic Research (now Innovation Fund Denmark, project 1305-00015B), The Programme Commission on Sustainable Energy and Environment. Funding from DTU is also gratefully acknowledged. The authors also acknowledge Aino Nielsen (Haldor Topsøe A/S) for technical assistant with the Raman spectroscopy, the Inorganic Analysis Department at Haldor Topsøe A/S for the elemental analysis of the fresh oxide precursors by inductive coupled plasma optical emission spectroscopy (IPC-OES), and the Organic Analysis Department at Haldor Topsøe A/S for analysis of the organic phase.

\section{References}

(1) Marker, T. L.; Felix, L. G.; Linck, M. B.; Roberts, M. J. Integrated Hydropyrolysis and Hydroconversion $\left(\mathrm{IH}^{2}\right)$ for the Direct Production of Gasoline and Diesel Fuels or Blending Components from Biomass, Part 1: Proof of Principle Testing. Environ. Prog. Sustain. Energy 2012, 31 (2), 191-199. 
https://doi.org/10.1002/ep.10629.

(2) Marker, T. L.; Felix, L. G.; Linck, M. B.; Roberts, M. J.; Ortiz-Toral, P.; Wangerow, J. Integrated

(4) Maleche, E.; Glaser, R.; Marker, T.; Shonnard, D. A Preliminary Life Cycle Assessment of Biofuels Produced by the $\mathrm{IH}^{2} \mathrm{TM}$ Process. Environ. Prog. Sustain. Energy 2014, 33 (1), 322-329. https://doi.org/10.1002/ep.11773.

(5) Fan, J.; Gephart, J.; Marker, T.; Stover, D.; Updike, B.; Shonnard, D. R. Carbon Footprint Analysis of Gasoline and Diesel from Forest Residues and Corn Stover Using Integrated Hydropyrolysis and Hydroconversion. ACS Sustain. Chem. Eng. 2016, 4 (1), 284-290.

https://doi.org/10.1021/acssuschemeng.5b01173.

(6) Dayton, D. C.; Carpenter, J.; Farmer, J.; Turk, B.; Gupta, R. Biomass Hydropyrolysis in a Pressurized Fluidized Bed Reactor. Energy \& Fuels 2013, 27 (7), 3778-3785. https://doi.org/10.1021/ef400355t.

(7) Dayton, D. C.; Hlebak, J.; Carpenter, J. R.; Wang, K.; Mante, O. D.; Peters, J. E. Biomass Hydropyrolysis in a Fluidized Bed Reactor. Energy \& Fuels 2016, 30 (6), 4879-4887. https://doi.org/10.1021/acs.energyfuels.6b00373.

(8) Wang, K.; Dayton, D. C.; Peters, J. E.; Mante, O. D. Reactive Catalytic Fast Pyrolysis of Biomass to 
Produce High-Quality Bio-Crude. Green Chem. 2017, 19 (14), 3243-3251.

https://doi.org/10.1039/C7GC01088E.

(9) Gamliel, D. P.; Wilcox, L.; Valla, J. A. The Effects of Catalyst Properties on the Conversion of Biomass via Catalytic Fast Hydropyrolysis. Energy \& Fuels 2017, 31 (1), 679-687.

https://doi.org/10.1021/acs.energyfuels.6b02781.

(10) Gamliel, D. P.; Bollas, G. M.; Valla, J. A. Bifunctional Ni-ZSM-5 Catalysts for the Pyrolysis and Hydropyrolysis of Biomass. Energy Technol. 2017, 5 (1), 172-182.

https://doi.org/10.1002/ente.201600136.

(11) Gamliel, D. P.; Bollas, G. M.; Valla, J. A. Two-Stage Catalytic Fast Hydropyrolysis of Biomass for the Production of Drop-in Biofuel. Fuel 2018, 216 (December 2017), 160-170.

https://doi.org/10.1016/j.fuel.2017.12.017.

(12) Şenol, O. I..; Ryymin, E.-M.; Viljava, T.-R.; Krause, A. O. I. Reactions of Methyl Heptanoate Hydrodeoxygenation on Sulphided Catalysts. J. Mol. Catal. A Chem. 2007, 268 (1-2), 1-8. https://doi.org/10.1016/j.molcata.2006.12.006.

(13) Şenol, O. I.; Viljava, T.-R.; Krause, A. O. I. Hydrodeoxygenation of Aliphatic Esters on Sulphided $\mathrm{NiMo} / \mathrm{Y}-\mathrm{Al}_{2} \mathrm{O}_{3}$ and CoMo/Y-Al2O3 Catalyst: The Effect of Water. Catal. Today 2005, 106, 186-189. https://doi.org/10.1016/j.cattod.2005.07.129.

(14) Şenol, O. I.; Viljava, T.-R.; Krause, A. O. I. Effect of Sulphiding Agents on the Hydrodeoxygenation of Aliphatic Esters on Sulphided Catalysts. Appl. Catal. A Gen. 2007, 326 (2), 236-244. https://doi.org/10.1016/j.apcata.2007.04.022.

(15) Ryymin, E.-M.; Honkela, M. L.; Viljava, T.-R.; Krause, A. O. I. Competitive Reactions and Mechanisms in the Simultaneous HDO of Phenol and Methyl Heptanoate over Sulphided NiMo/ $/ \mathrm{Al}_{2} \mathrm{O}_{3}$. Appl. 
Catal. A Gen. 2010, 389 (1-2), 114-121. https://doi.org/10.1016/j.apcata.2010.09.010.

(16) Gutierrez, A.; Turpeinen, E.-M.; Viljava, T.-R.; Krause, O. Hydrodeoxygenation of Model Compounds on Sulfided CoMo/Y-Al2O3 and NiMo/Y-Al2O3 Catalysts; Role of Sulfur-Containing Groups in Reaction Networks. Catal. Today 2017, 285, 125-134. https://doi.org/10.1016/j.cattod.2017.02.003.

Dabros, T. M. H.; Gaur, A.; Pintos, D. G.; Sprenger, P.; Høj, M.; Hansen, T. W.; Studt, F.; Gabrielsen, J.; Grunwaldt, J.-D.; Jensen, A. D. Influence of $\mathrm{H} 2 \mathrm{O}$ and $\mathrm{H} 2 \mathrm{~S}$ on the Composition, Activity, and Stability of Sulfided Mo, CoMo, and NiMo Supported on MgAl2O4 for Hydrodeoxygenation of Ethylene Glycol. Appl. Catal. A Gen. 2018, 551 (October 2017), 106-121. https://doi.org/10.1016/j.apcata.2017.12.008.

(18) Bui, V. N.; Laurenti, D.; Afanasiev, P.; Geantet, C. Hydrodeoxygenation of Guaiacol with CoMo Catalysts. Part I: Promoting Effect of Cobalt on HDO Selectivity and Activity. Appl. Catal. B Environ. 2011, 101 (3-4), 239-245. https://doi.org/10.1016/j.apcatb.2010.10.025.

(19) Centeno, A.; Laurent, E.; Delmon, B. Influence of the Support of CoMo Sulfide Catalysts and of the Addition of Potassium and Platinum on the Catalytic Performances for the Hydrodeoxygenation of Carbonyl, Carboxyl, and Guaiacol-Type Molecules. J. Catal. 1995, 154 (2), 288-298. https://doi.org/10.1006/jcat.1995.1170.

(20) Badawi, M.; Paul, J.-F.; Cristol, S.; Payen, E. Guaiacol Derivatives and Inhibiting Species Adsorption over $\mathrm{MoS}_{2}$ and CoMoS Catalysts under HDO Conditions: A DFT Study. Catal. Commun. 2011, 12 (10), 901-905. https://doi.org/10.1016/j.catcom.2011.02.010.

(21) Trinh, T. N.; Jensen, P. A.; Dam-Johansen, K.; Knudsen, N. O.; Sørensen, H. R.; Hvilsted, S. Comparison of Lignin, Macroalgae, Wood, and Straw Fast Pyrolysis. Energy \& Fuels 2013, 27 (3), 1399-1409. https://doi.org/10.1021/ef301927y. 
(22) Raybaud, P.; Hafner, J.; Kresse, G.; Kasztelan, S.; Toulhoat, H. Structure, Energetics, and Electronic Properties of the Surface of a Promoted MoS2 Catalyst: An Ab Initio Local Density Functional Study. J. Catal. 2000, 190 (1), 128-143. https://doi.org/10.1006/jcat.1999.2743.

(23) Leliveld, B. R. G.; van Dillen, J. A. J.; Geus, J. W.; Koningsberger, D. C.; de Boer, M. Structure and Nature of the Active Sites in CoMo Hydrotreating Catalysts. An EXAFS Study of the Reaction with Selenophene. J. Phys. Chem. B 1997, 101 (51), 11160-11171. https://doi.org/10.1021/jp9723933.

(24) Topsøe, H.; Clausen, B. S.; Massoth, F. E. Catalysis - Science and Technology. Hydrotreating Catalysis, Volume 11.; Springer-Verlag: Berlin Heidelberg, Germany, 1996.

(25) Bouvier, C.; Romero, Y.; Richard, F.; Brunet, S. Effect of $\mathrm{H}_{2} \mathrm{~S}$ and $\mathrm{CO}$ on the Transformation of 2Ethylphenol as a Model Compound of Bio-Crude over Sulfided Mo-Based Catalysts: Propositions of Promoted Active Sites for Deoxygenation Pathways Based on an Experimental Study. Green Chem. 2011, 13 (9), 2441-2451. https://doi.org/10.1039/c1gc15181a.

(26) Bui, V. N.; Laurenti, D.; Delichère, P.; Geantet, C. Hydrodeoxygenation of Guaiacol. Part II: Support Effect for CoMoS Catalysts on HDO Activity and Selectivity. Appl. Catal. B Environ. 2011, 101 (3-4), 246-255. https://doi.org/10.1016/j.apcatb.2010.10.031.

(27) Gonçalves, V. O. O.; Brunet, S.; Richard, F. Hydrodeoxygenation of Cresols over $\mathrm{Mo} / \mathrm{Al}_{2} \mathrm{O}_{3}$ and CoMo/ $/ \mathrm{Al}_{2} \mathrm{O}_{3}$ Sulfided Catalysts. Catal. Letters 2016, 146 (8), 1562-1573.

https://doi.org/10.1007/s10562-016-1787-5.

(28) Schachtl, E.; Yoo, J. S.; Gutiérrez, O. Y.; Studt, F.; Lercher, J. A. Impact of Ni Promotion on the Hydrogenation Pathways of Phenanthrene on $\mathrm{MoS}_{2} / \mathrm{Y}-\mathrm{Al}_{2} \mathrm{O}_{3}$. J. Catal. 2017, 352, 171-181. https://doi.org/10.1016/j.jcat.2017.05.003.

(29) Stummann, M. Z.; Høj, M.; Schandel, C. B.; Hansen, A. B.; Wiwel, P.; Gabrielsen, J.; Jensen, P. A.; 
Topsøe, H. The Role of Co-Mo-S Type Structures in Hydrotreating Catalysts. Appl. Catal. A Gen. 2007, 322 (SUPPL.), 3-8. https://doi.org/10.1016/j.apcata.2007.01.002.

(32) Wivel, C.; Candia, R.; Clausen, B. S.; Mørup, S.; Topsøe, H. On the Catalytic Significance of a CoMoS Phase in CoMo Al2O3hydrodesulfurization Catalysts: Combined in Situ Mössbauer Emission Spectroscopy and Activity Studies. J. Catal. 1981, 68 (2), 453-463. https://doi.org/10.1016/00219517(81)90115-9.

(33) Stummann, M. Z.; Høj, M.; Davidsen, B.; Hansen, A. B.; Hansen, L. P.; Wiwel, P.; Schandel, C. B.; Gabrielsen, J.; Jensen, P. A.; Jensen, A. D. Effect of the Catalyst in Fluid Bed Catalytic Hydropyrolysis. Catal. Today 2019. https://doi.org/https://doi.org/10.1016/j.cattod.2019.01.047.

(34) Laurent, E.; Delmon, B. Study of the Hydrodeoxygenation of Carbonyl, Carboxylic and Guaiacyl Groups over Sulfided CoMo $/ \mathrm{Y}-\mathrm{Al}_{2} \mathrm{O}_{3}$ and $\mathrm{NiMo} / \mathrm{Y}-\mathrm{Al}_{2} \mathrm{O}_{3}$ Catalyst: II. Influence of Water, Ammonia and Hydrogen Sulfide. Appl. Catal. A Gen. 1994, 109 (1), 97-115.

(35) Leflaive, P.; Lemberton, J. L.; Pérot, G.; Mirgain, C.; Carriat, J. Y.; Colin, J. M. On the Origin of Sulfur Impurities in Fluid Catalytic Cracking Gasoline - Reactivity of Thiophene Derivatives and of Their Possible Precursors under FCC Conditions. Appl. Catal. A Gen. 2002, 227 (1-2), 201-215. https://doi.org/10.1016/S0926-860X(01)00936-X. 
646 (36) Corma, A.; Martínez, C.; Ketley, G.; Blair, G. On the Mechanism of Sulfur Removal during Catalytic

Cracking. Appl. Catal. A Gen. 2001, 208 (1-2), 135-152. https://doi.org/10.1016/S0926-

(37) Dos Santos, N.; Dulot, H.; Marchal, N.; Vrinat, M. New Insight on Competitive Reactions during Deep HDS of FCC Gasoline. Appl. Catal. A Gen. 2009, 352 (1-2), 114-123.

https://doi.org/10.1016/j.apcata.2008.09.035.

(38) Anabtawi, J. A. gregdffds.; Ali, S. A.; Abdul Bari Siddiqui, M.; Javaid Zaidi, S. M. Factors Influencing the Performance of Naphtha Hydro-Desulfurization Catalysts. In Catalysts in Petroleum Refining and Petrochemical Industries 1995; 1996; pp 225-234. https://doi.org/10.1016/S0167-2991(96)80023-1.

(39) Si, X.; Xia, D.; Xiang, Y.; Zhou, Y. Effect of H2S on the Transformation of 1-Hexene over NiMoS/YAl2O3 with Hydrogen. J. Nat. Gas Chem. 2010, 19 (2), 185-188. https://doi.org/10.1016/S10039953(09)60054-2.

(40) Mortensen, P. M.; Gardini, D.; Damsgaard, C. D.; Grunwaldt, J.-D.; Jensen, P. A.; Wagner, J. B.; Jensen, A. D. Deactivation of Ni-MoS 2 by Bio-Oil Impurities during Hydrodeoxygenation of Phenol and Octanol. Appl. Catal. A Gen. 2016, 523, 159-170. https://doi.org/10.1016/j.apcata.2016.06.002.

(41) Anca-Couce, A. Reaction Mechanisms and Multi-Scale Modelling of Lignocellulosic Biomass Pyrolysis. Prog. Energy Combust. Sci. 2016, 53, 41-79. https://doi.org/10.1016/j.pecs.2015.10.002.

(42) Dabros, T. M. H. A Step in Understanding and Optimizing Fuel Production from Solid Biomass PhD Thesis, Technical University of Denmark, Dept. of Chemical and Biochemical Engineering, 2017.

(43) Hardcastle, F. D.; Wachs, I. E. Determination of Molybdenum-oxygen Bond Distances and Bond Orders by Raman Spectroscopy. J. Raman Spectrosc. 1990, 21 (10), 683-691. https://doi.org/10.1002/jrs.1250211009. 
668 (44) Hu, H.; Wachs, I. E. Surface Structures of Supported Molybdenum Oxide Catalysts. Characterization 669 by Raman and Mo L3-Edge XANES. J. Phys. Chem. 1995, 99 (27), 10897-10910. https://doi.org/10.1021/j100027a034.

(46) Mortensen, P. M.; Gardini, D.; de Carvalho, H. W. P.; Damsgaard, C. D.; Grunwaldt, J.-D.; Jensen, P. A.; Wagner, J. B.; Jensen, A. D. Stability and Resistance of Nickel Catalysts for Hydrodeoxygenation: Carbon Deposition and Effects of Sulfur, Potassium, and Chlorine in the Feed. Catal. Sci. Technol. 2014, 4 (10), 3672-3686. https://doi.org/10.1039/c4cy00522h.

(47) Hansen, L. P.; Johnson, E.; Brorson, M.; Helveg, S. Growth Mechanism for Single- and Multi-Layer MoS2 Nanocrystals. J. Phys. Chem. C 2014, 118 (39), 22768-22773.

https://doi.org/10.1021/jp5069279. 